\title{
A Study and Assessment of the Carbon Footprint of Tianjin University's Weijin Road and Peiyangyuan Campuses, China
}

abduxukur zayit

Tianjin University https://orcid.org/0000-0002-3469-1124

Kun Song ( $\square$ imsongkun@126.com )

tian jin da xue: Tianjin University

Antariksh Bhagwan Ghengare

Tianjin University

Feng Gao

Tianjin University

\section{Research}

Keywords: Carbon neutrality, Colleges and universities, Carbon footprint, Tianjin university, GHG accounting, Sustainable university, Zero-emission university, Carbon offsetting, University campus, Per capita carbon footprint

Posted Date: November 8th, 2021

DOI: https://doi.org/10.21203/rs.3.rs-1021871/v1

License: (c) (i) This work is licensed under a Creative Commons Attribution 4.0 International License. Read Full License 


\section{A Study and Assessment of the Carbon Footprint of}

\section{Tianjin University's Weijin Road and Peiyangyuan}

\section{Campuses, China}

Abduxukur Zayit ${ }^{1 \text { and } 2}$, Kun Song ${ }^{1 *}$, Antariksh Bhagwan Ghengare ${ }^{1}$, Feng Gao $^{1}$

${ }^{1}$ School of Architecture, Tianjin University, Tianjin 300072, China;

${ }^{2}$ College of Hydraulic and Civil Engineering, Xinjiang Agricultural University, Ürümchi, Xinjiang Uyghur Autonomous region,830052, China)

* Correspondence author, E-mail: imsongkun@126.com (K.S.)

\section{Abstract}

Background: A living University campus is like a model city; its energy and carbon auditing can also model how energy and carbon can be studied and analyzed in a city. China's colleges and universities face grave problems, now and in the future - from declining quality of campus environments to deteriorating building performance, antiquated facilities, and inefficient energy and resources consumption. While research and discussion exists on improving existing university buildings' energy performance and evaluation standards - much of that research focuses on energy savings, rather than on greenhouse gas emissions reductions. Calculation of campus carbon emissions is the first step for transforming and planning each existing university to carbon neutral campus. Some researchers of campus carbon emissions in China have made calculations, which, although as yet unpublished, create an initial framework for carbonneutral campus plan targets. The present research gives an overview of universities' 
drive towards sustainability in China and in other countries. The paper then details carbon footprint accounting steps, quantifying major carbon emission sources and carbon sequestration by vegetation inside the Tianjin University's Weijin Road and Peiyangyuan Campuses. Results from China's universities are compared with international results in the scientific literature. In this paper, based on this data, we suggest strategies and show preliminary target settings for how to transform Weijin Road into a carbon-neutral campus.

Results: Annual carbon emissions for 2019 of the Weijin Road campus were 58,172.68 tonnes, (2.60 tonnes per person), and Peiyangyuan campus, 55,213.75 tonnes (2.46 tonnes per person). The largest sources of the two campuses' greenhouse gas emissions were electricity and gas; Weijin Road campus; electricity $=61.42 \%$, gas $=20.73 \%$, and Peiyangyuan campus electricity $=69.32 \%$, gas $=11.60 \%$. Carbon sequestered in the two campuses by vegetation are $11,257.34$ tonnes and 27,856.51 tonnes respectively. The renewable energy contribution to carbon reduction in Peiyangyuan campus is 50.85 tonnes.

Conclusion: Per person carbon emissions of Tianjin University's two campuses are below the average for some US campuses, but are also greater than some in European countries. Research may investigate methods used by successful campuses towards becoming carbon neutral.

Keywords: Carbon neutrality, Colleges and universities, Carbon footprint, Tianjin university, GHG accounting, Sustainable university, Zero-emission university, Carbon offsetting, University campus, Per capita carbon footprint 
Paper Type: Research Paper

\section{Introduction}

Climate Change caused by daily human activity is threatening the sustainability of the earth and confronting Climate Change is critical for the sustainable development of the Earth (Edenhofer, 2015). In 1988 an intergovernmental UN body, the Intergovernmental Panel on Climate Change (IPCC) was established, 1990 IPCC completed its first report and concluded that the global mean surface air temperature has increased by 0.3 to $0.6{ }^{\circ} \mathrm{C}$ over the last 100 years (IPCC, 1990). The increase of greenhouse gases $(\mathrm{GHG})$ in the atmosphere is the main reason for Climate Change, and water vapor, carbon dioxide $\left(\mathrm{CO}_{2}\right)$, methane $\left(\mathrm{CH}_{4}\right)$, nitrous oxide $\left(\mathrm{N}_{2} \mathrm{O}\right)$, and ozone are considered to be the main parts of GHG total emissions and those gases are called carbon footprint, or $\mathrm{CO}_{2 \mathrm{eq}}$ when accounting for these gasses as the results are easy to compare. To reduce GHG emissions, in 1997 the Kyoto protocol was adopted in Kyoto, Japan. The protocol requested countries to adopt necessary policies and measures to limit the GHG emissions and report their efforts periodically. Unfortunately, this failed mainly because some countries were not bound by the Kyoto Protocol, notably China and the United States, which together were responsible for approximately 40 percent of global carbon dioxide emissions (Rosen, 2015). In 2015, world leaders established the Paris Agreement, which pledged to control the temperature rise of $2^{\circ}$ compared with the Pre-industrial time (1850-1900). Although in recent years there have been pledges and other carbon reduction related policies implemented by countries, the most recent being the IPCC report which noted that the past five years have been the hottest on record since 1850 . The 2021 report also suggests that human activity is changing the climate in 
an unprecedented and sometimes irreversible way (McGrath, 2021).

China is now the world's

largest carbon emission

contributor since 2006 (Fig.

1), according to the

International Energy Agency

statistics, and by the end of

2019, total carbon emissions

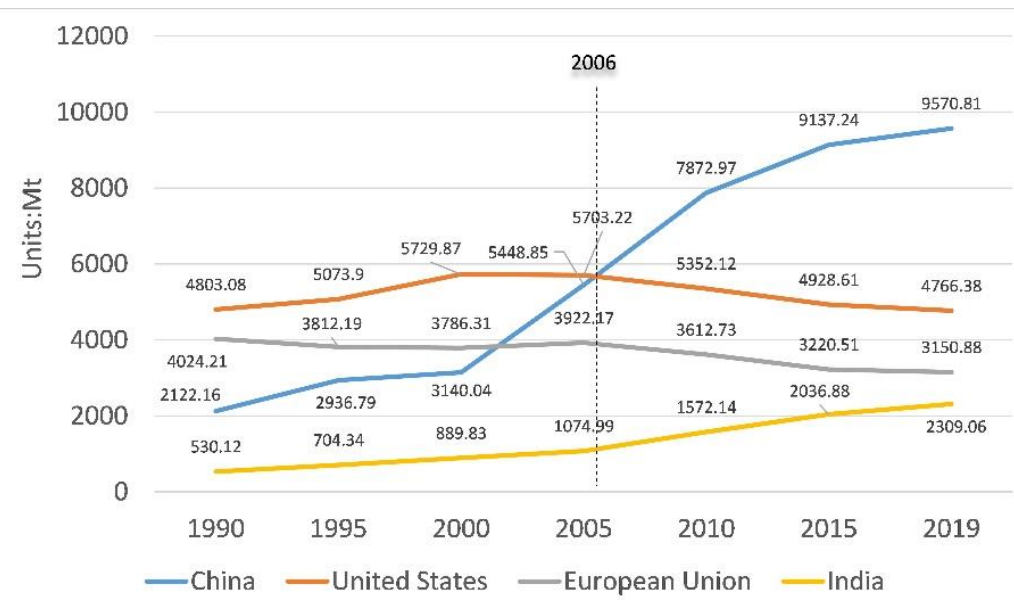

Fig. 1. World Major Countries and their $\mathrm{CO}_{2}$ Emission Source: International Energy Agency (IEA), author A.Zayit in China were $9.57 \mathrm{Gt}$ (Gigatonnes) of $\mathrm{CO}_{2}$, which accounts for about $28 \%$ of total world carbon emission (IEA, 2021). Most recent studies and news reports suggest that China's GHG emission is critical to the world (Brown, 2021). With the growing attention to Climate Change, in the $75^{\text {th }}$ UN meeting, China announced an ambitious 'Plan to reducing GHG Emissions" and set a target for the country, known as the "30-60" target, whereby 2030 will reach the peak value of the GHG emission and 2060 will reach carbon-neutral country (China Plus, 2020).

Climate Change is an important topic, and many organizations and universities have realized the importance of mitigating their carbon footprint, and some have completed their greenhouse gas inventories to determine their greenhouse potential, which is the first step towards a planned carbon emission target (Roche et al., 2014). Colleges and Universities are seen as an important part of society with the main characteristic of a high density of population, and high energy consumption. Finding how to reduce colleges and universities carbon emissions is now an important reference and challenge for the whole of society. 
Between 5-16 June 1972, the United Nations Conference on the Environment was held in Stockholm, Sweden, and for the first time mentioned 'green school', but that particular reference concerned environment-related teaching (NATIONS, 1972). In 1987, the World Commission on Environment and Development (WCED) published the Brundtland Report, also called 'Our Common Future', and introduced the concept of sustainable development (Lélé, 1991). In 1990, 350 universities from 40 countries around the world signed the Talloires Declaration (Butt et al., 2009), and emphasized the role of universities in sustainable development, and agreed to the 10 action plans of sustainability (University, 1990), and as of February 2021, total signatory institutions reached 519 (Future, 2021). Universities began to pay attention to the sustainable problems, with the introduction of 'COPERNICUS University Charter for Sustainable Development, which started to raise awareness of 'Sustainability' throughout Europe (UNECE, 2005). December 1991, 33 Higher Institutions from 10 countries on 5 continents signed the Halifax Declaration (Evangelinos et al., 2009), emphasizing the role of Higher Institutions in education, research and the public service sector's sustainable development. In December 2002, United Nations General Assembly proclaimed the 'The United Nations Decade of Education for Sustainable Development' (DESD, 2005-2014), its aims were to reorient education policy, practice and investment to address sustainability, bringing world focus to the important issues of education for sustainable development (UNESCO, 2022).

On April 22, 2010, Higher Education Institutions (HEIs) signed the American College and University Presidents' Climate commitment (ACUPCC), amid increasing concerns for Climate Change. It premised the initiative for universities and colleges to 
113 be carbon neutral before 2030, as ACUPCC implored universities to change direction

114 for carbon emission, and was applied to approximately 400 colleges and universities 115 which signed the agreement (Denison, 2010). In summary, 'green school' initially 116 started outside of China from a sustainability concept. This developed into 117 environmental education and from there it developed to include higher education, 118 colleges and universities holding various conferences, and signed declarations which 119 ultimately pushed colleges and universities into a sustainable campus direction.

In 1996, The Chinese Ministry of Environmental Protection published the 'National Action Plan' for environmental publicity and education, demanding conduct of "Green School" activities throughout the country (China, 1996). In 1999, the Ministry published the 'National Environmental Education and Promotion Plan for 2001-2005', which proclaimed the 'Green University' (China, 2001). October 2009 Ministry of Housing and Urban-Rural Development published 'Technical Guide for Colleges and Universities Building Energy Efficiency Supervision System’ (China, 2009) providing a guide for Chinese colleges and universities to establish 'Conservation-Oriented Campuses'.

The Chinese government later published various guidelines and technical guides for building energy saving, ecological campus and more. Most recently, September 8, 2021, the Ministry of Housing and Urban-Rural Development of the People's Republic of China (MOHURD) published the 'General standard for building energy conservation and renewable energy utilization'. It is the first mandatory standard in Chinese building history which requires all new and renovated buildings to meet the carbon emission reductions requirements (effective April 1, 2022) (China, 2021). The 'National 
Assessment Standard' for 'Green Campus' (GB/T51356-2019) was officially launched in October 2019 (Ministry Of Housing And Urban-Rural Development, 2019). This standard was composed of five major parts, which are: 1. Planning and Ecology, 2. Energy and Resources, 3. Environment and Health, 4. Operation and Management, 5. 140 Education and Spread. China's higher education campus construction developed from 141 Energy-Saving Campus to Technical Standards and then to National Standards which concentrate mainly on 'Campus Energy Saving' (Zhu et al., 2021) (Zhu and Dewancker, 143 2021), which ultimately led to the 'Green Campus' in China. common in Chinese colleges and universities to calculate the carbon footprint. This is mainly because there are few sustainable assessment tools for colleges and universities in China from the perspective of carbon emission evaluation. The assessment standard for the Green Campus in China included only a few points of the carbon assessment indicator which concentrated on-campus buildings, but the standards and technical guidelines were unable to measure and evaluate carbon emissions for the whole campus, which could not meet the current demand for creating a carbon-neutral campus.

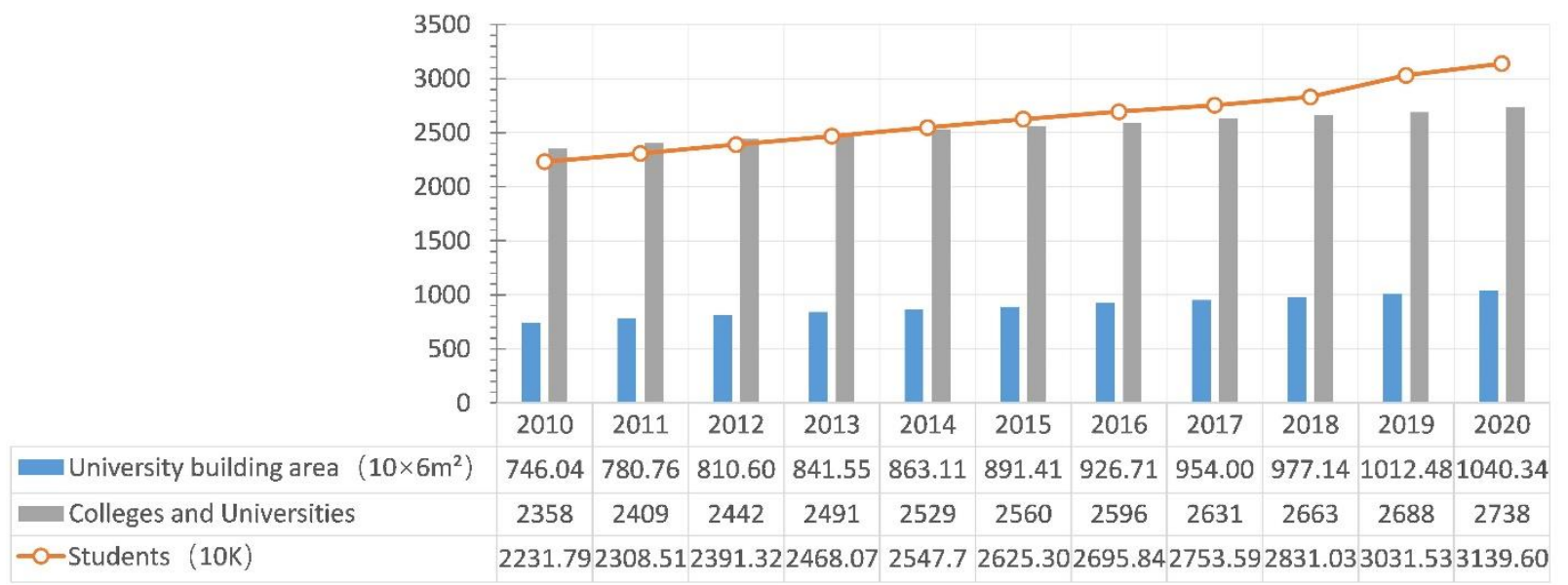

Fig. 2 Statistics of colleges and universities in China, From 2010-2020 Source: Data from educational statistics yearbook of China, author A.Zayit 

country in the world. By the end of 2019, there were 2688 colleges and universities, with over 30.31 million students enrolled in mainland China (Fig. 2). The education system includes Bachelors, Masters and Doctoral degrees, as well as non-degree programs, and is also open to foreign students.

Colleges and universities'

building area built before 2010

makes up $73.68 \%$ of total

160 building area (Fig. 3), which

means many campus buildings

across China cannot meet

"Green" building standards.

Some of them have been

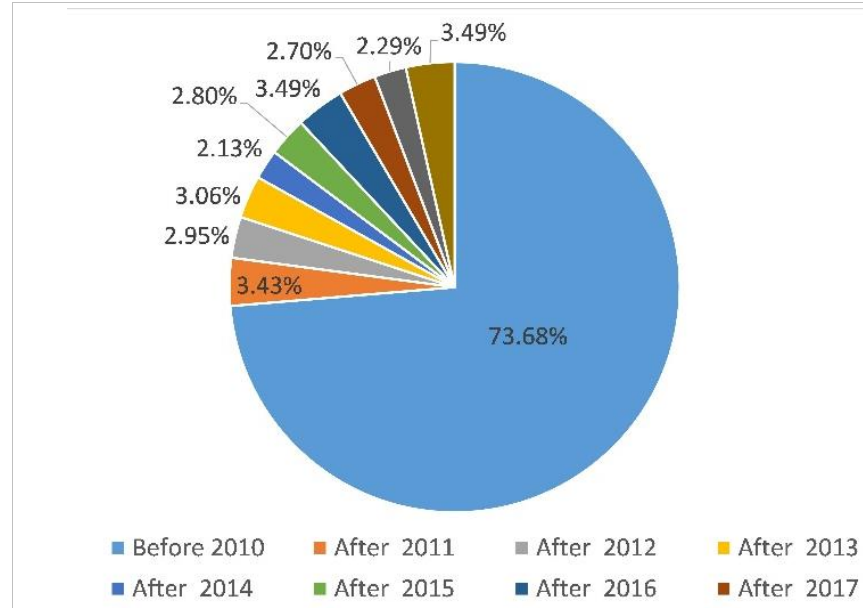

Fig. 3. University buildings year of construction

Source: Data from educational statistics yearbook of China, author A.Zayit renovated, although only a limited number. in Tongji University in Shanghai, PRC. 44 colleges and universities across China joined the global and national ambition for carbon neutrality and signed the Declaration on Carbon Neutrality of Chinese Colleges and Universities by 2050 (Development, 2021).

This paper assesses the GHG emissions of the first university in modern Chinese

171 history. Firstly, it assesses and analyzes major carbon emission sources of the Weijin

172 Road (Old) Campus and the Peiyangyuan (New) campus of Tianjin University (Fig. 4),

173 Tianjin, China by selecting electricity, natural gas (used for heating and cooking), transportation, waste generation, human activity, and tap water, as the target research. 
175 These areas have been selected by other researchers, where they also calculate the carbon footprint of universities (Yazdani et al., 2013, Ridhosari and Rahman, 2020).

Secondly, this paper also attempts to explain how the calculations are carried out, and finally, comparing two campuses' carbon emission results with other universities around the world, giving an explanation and strategies to help develop and transform.

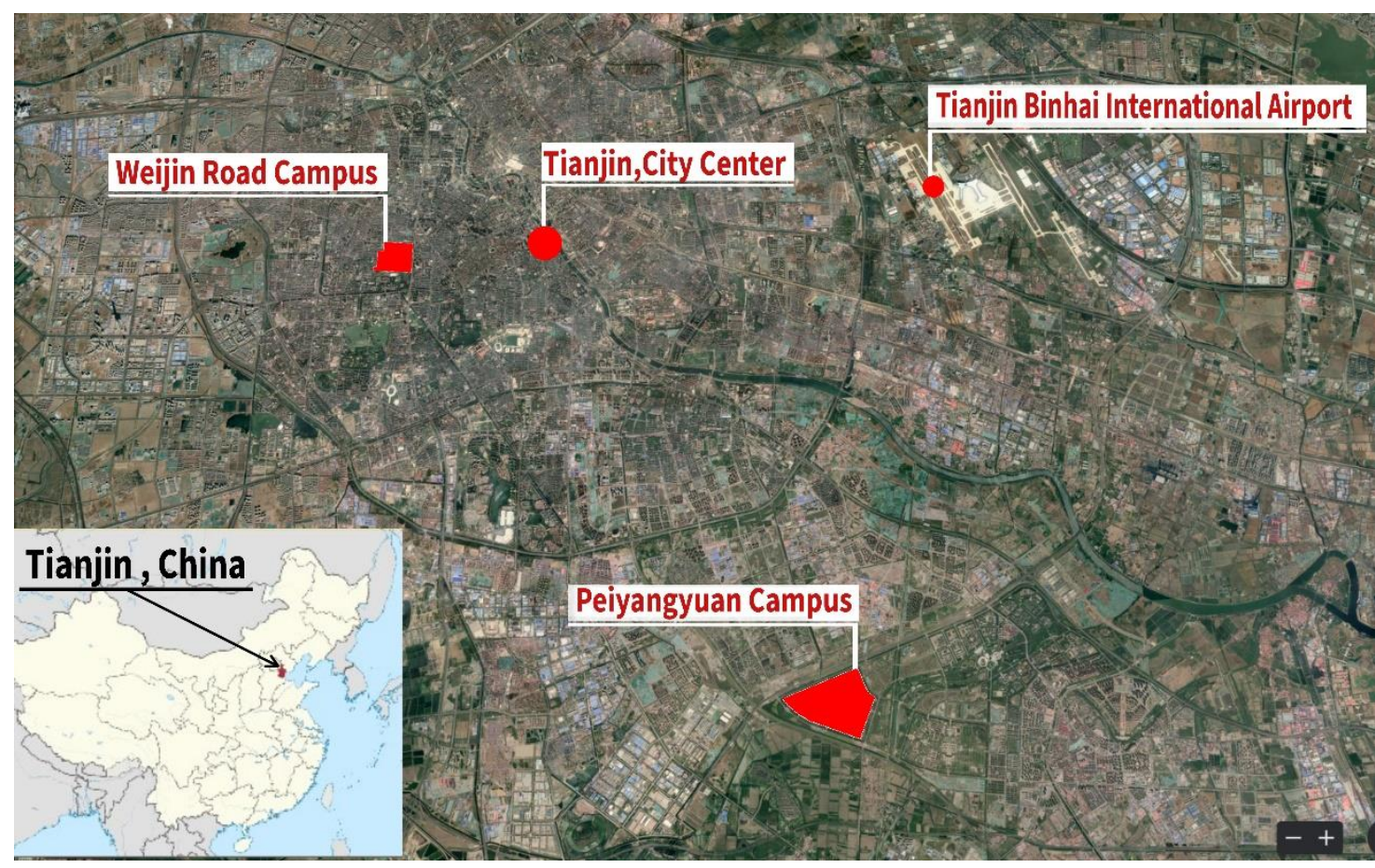

Fig. 4 Tianjin, China, and TJU two campuses relationship map, author A.Zayit

\section{Review of carbon footprinting of colleges and universities}

The first step for reducing GHG on campus is the calculation of carbon emissions that are emitted by campus activities, which is the basis for further development and implementation of carbon reduction strategies. To quantify carbon emission, the concept of carbon footprint emerged, with the carbon footprint concept coming from the ecological footprint. In 1990, Mathis Wackernagel and William Rees introduced the concept of Ecological Footprint'(Wackernagel and Rees, 1998), which according to the 
ecological footprint is the carbon footprint as an area of the earth that needs to absorb emission produced by one person's whole life. Although many articles and research have been done regarding carbon footprint, until 2007, not everything was clear. In 2007, Thomas Wiedmann and Jan Minx provided clearer definitions of the carbon footprint and introduced the calculation method of $\mathrm{CO}_{2}$, which considers a full life-cycle approach (Wiedmann and Minx, 2008) and the ISO 14064 (Greenhouse Gas Validation and Verification https://www.lr.org/en/iso-14064 ) standards which also uses life cycle assessment methods (Sangwan et al., 2018).

Calculating carbon emissions of university campuses is challenging, with the main obstacle being the lack of data for the calculations. Nunes, Catariono, Teixeria M R. put forward a framework for the inter-comparison of the ecological footprint of universities [J] entitled: ECOLOGICAL INDICATORS, but this method required repeated calculations with some inherent uncertainties (Nunes et al., 2013).

In the academic field, calculating the environmental impacts of a university started to consider beyond a single building and it began to emphasize operational stage calculations. For example, Aly Abdelalim calculated 45 educational buildings carbon emissions in Canadian universities (Abdelalim et al., 2015). Chia Chien Chang studied Nanyang Technological University's (NTU) 22 academic buildings, with a study showing that energy consumption in the operational stage is between $63 \%$ and $95 \%$, while the remaining 5\%-37\% is from embodied energy. This suggested the necessity for expanding the research to the non-academic buildings to better understand overall campus' embodied carbon emissions, and it established a local database for major building materials to ensure higher accuracy for calculation of embodied energy(Chang 
et al., 2019), meaning that the operational stage made the most emissions.

Results from further studies also suggest that transportation and carbon sequestration of green plants also contribute a large part to carbon emissions, for example: the University of Talca's carbon emissions results show the transportation of people produced the highest contribution of $0.41 \mathrm{tCO}_{2}$ e per person (Yañez et al., 2020a). The University Teknologi Malaysia (UTM) considered air transportation utilized by university students and employees contributed $34.74 \%$ and electricity usage contributed 19.37\% (Naderipour et al., 2021). Pusan National University campus carbon emissions calculated the movement of the campus' members which were $21.5 \%$ (Jung et al., 2016), and the University of 'Lille 1' calculated the mobility users as 56\% (Bouscayrol et al., 2017).

Carbon absorption by vegetation also cannot be ignored. For example, studies show that the green belt in the SVNIT campus is absorbing 76.92 to $84.63 \%$ of $\mathrm{CO}_{2}$ emission annually (Suresh et al., 2021), Shandong Jianzhu University carbon sequestration of green spaces in 2015 was 11936 tonnes, which was equal to about $34.7 \%$ of the total carbon emissions (ZOURan, 2017).

In summary, studies have shown that campus carbon accounting emphasizes both special and temporal circumstances.

(1) Quantifying campus carbon footprint should emphasize the whole campus. It is necessary to move the carbon neutrality calculations beyond campus buildings and this should include buildings, mobility, carbon sequestration, and carbon reduction as a result of renewable resources.

(2) Studies related to the carbon emissions calculations of campuses mostly 
emphasize the operational stage of a university campus.

(3) In the selection of carbon accounting objectives, due to their high percentages, studies have suggested including the importance of calculating carbon emission of mobility and the sequestration of green plants on campus (Bouscayrol et al., 2017, Suresh et al., 2021, ZOURan, 2017).

\section{Study area and methodology of work}

\subsection{Case Study: Tianjin University}

Tianjin University (TJU) was founded in 1895 as Peiyang University and is the first university in modern (1840-1919) Chinese history. In 1951, Peiyang University and Hebei Technical College combined under the name of TJU. The University has 3 campuses, and this research aims to calculate the carbon emission of TJU Weijin Road Campus (old campus) and Peiyangyuan Campus (new campus). The total numbers of domestic and foreign students, academic staff, and non-academic staff can be seen in Table 1.

Table 1 TJU'S Weijin Road and Peiyangyuan Campus's characteristics in 2019

\begin{tabular}{cccc}
\hline & Weijin Road Campus & Peiyangyuan Campus & Total \\
\hline Academic staff & 2569 & 2500 & 5069 \\
Undergraduates & 10004 & 9784 & 19788 \\
Postgraduates & 8247 & 9080 & 17327 \\
Foreign students & 1243 & 824 & 2067 \\
Non-academic staff & 300 & 300 & 600 \\
Total & 22363 & 22488 & 44851 \\
\hline
\end{tabular}

Source: TJU Office of Student Affairs \& Office of Human Resources

\subsubsection{Study area configuration}

TJU Weijin Road campus enclosed areas is $1,362,000 \mathrm{~m}^{2}$. TJU Peiyangyuan campus enclosed areas is $2,436,000 \mathrm{~m}^{2}$ (University, 2020a) . Weijin Road Campus is 
divided into two parts, Part $\mathrm{A}$ is the main campus area and it has three entry gates each marked with a number in the figure. Part B is the old and extended parts of TJU Weijin

Road Campus and no longer part of the university, and therefore it can be excluded as it doesn't have any energy relationship with the study area (Fig. 5). teaching buildings, laboratories, libraries, logistics, all canteens, etc.) under the control

262 building.

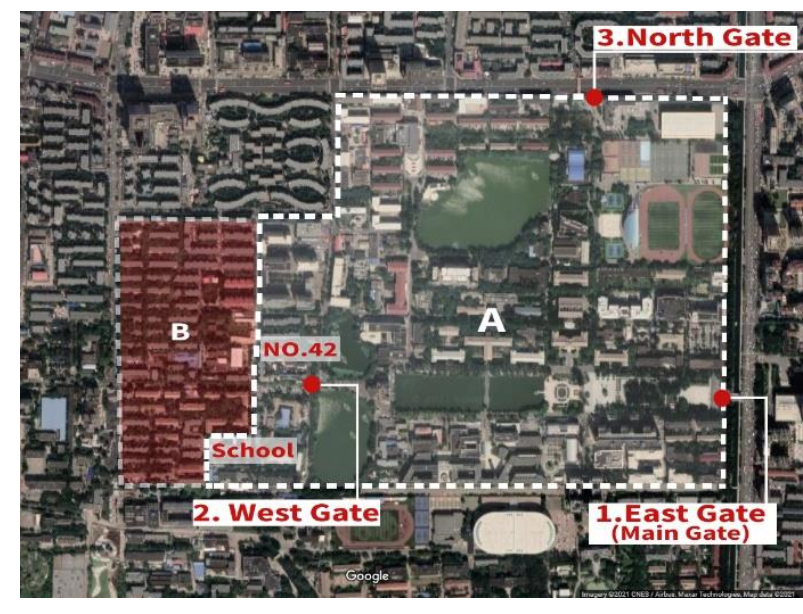

\section{Legend:}

(A)Weijin Road Campus

1.East Gate

2.West Gate

3.North Gate

(B) Not forming part of campus

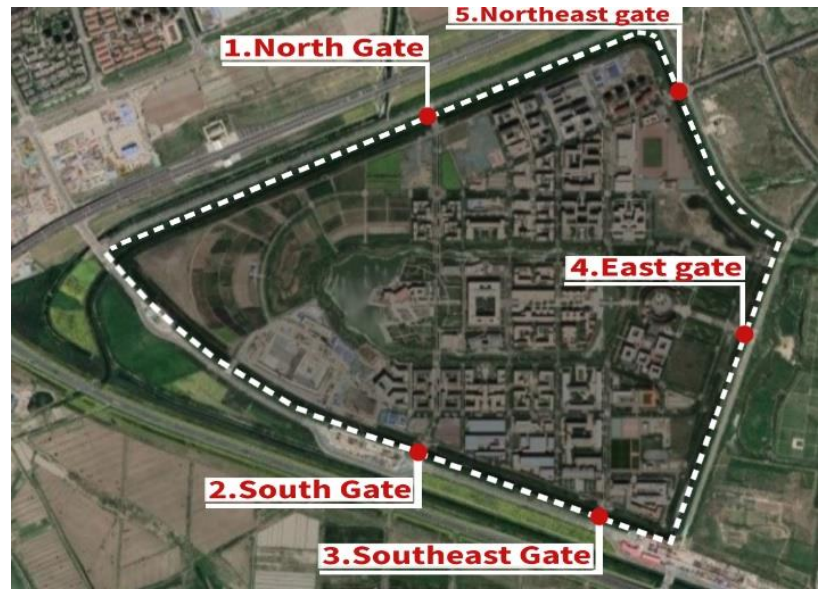

\section{Legend:}

Peiyangyuan Campus

1.North Gate

4. East Gate

2.South Gate

5. Northeast Gate

3.Southeast Gate

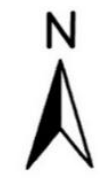

Fig. 5 TJU'S Weijin Road and Peiyangyuan Campus's study area

\subsubsection{Scope and phases considered}

Many universities around the world have considered the carbon footprint of the 
mobility of students and staff from outside the campus area where its impact is normally lower than that of electricity (Helmers et al., 2021). The situation in China is not the same and is impractical to calculate due to the very high number of students and staff. Students and staff at TJU travel from various parts of China, and they have various modes of transport, making it difficult to predict or anticipate when and where mobility occurred. Some studies have suggested questionnaire-based calculations for the mobility of students and staff (Helmers et al., 2021), but due to the long distances covered and the mobility situation in China, 'questionnaires' for the thousand (two campuses with a combined population of approximately 45000 people in total) were beyond the scope of this study - but an estimate would be sufficient rather than attaining precise and reliable travel statistics from outside the campus.

The carbon footprint of a university should be intrinsically focused on emissions caused by activities within the campus, rather than the mobility of students and staff occurring outside of the campus boundary which cannot be controlled by the university. It is also supported by Isiaka Adeyemi Abdul-Azeez, who pointed out in his research that carbon emission assessment should be focused on the sources which a university authority has control over where carbon emission strategies could be applied (Adeyemi, 2018).

In this regard, this research considers electricity, natural gas (heating and canteen cooking), and mobility of cars within the campus, solid waste generation, tap water, and human activity are each quantified for carbon emission accounting. Data was collected to quantify the 'operational stage' of GHG emissions of the two campuses in 2019. 


\subsection{Selection of Carbon footprinting accounting method}

There are several standards for quantifying greenhouse gas emissions; IPCC, GHG

Protocol, PAS2050, and ISO14064. IPCC is mainly for countries around the world to assess their carbon emission inventories and calculation methods. Countries make their reports and submit to the UN about the emission status and plans of reduction (Arndt et $a l ., 2020)$. GHG Protocol is established by the World Resources Institute (WRI) and the World Business Council for Sustainable Development (WBCSD) (WRI, 2004), PAS2050 is established by the British Standards Institution (BSI) (García and Freire, 2014). These two carbon emission systems are mainly for quantifying product and product-related services. ISO14064 is established by the International Organization for Standardization (ISO), which is a standard to calculate Greenhouse Gas emissions and Carbon Footprints (Wintergreen and Delaney, 2007).

As discussed earlier, PAS 2050 is mainly for products and their service and is not suitable for colleges and universities carbon emission calculations. IPCC is the most recognized carbon emission calculation standard at a national level, however, it is not suitable for China's present energy structure status and development.

Quantification of GHG emission methods vary among universities, some use ISO 14064 standards and some universities around the world use a corporate accounting and reporting standard - GHG Protocol (WBCSD, 2004), but of this study, we established a carbon footprint calculation method, using both IPCC, ISO14064 and officially authenticated documents, standards, and regulations relevant to China. IPCC sets the target of carbon emission, the carbon absorption ISO14064 method, categorizing carbon emission sources, and finally, China's national standard 'General rules' have been 
applied for calculating the comprehensive energy consumption, GB/T 2589-2020

(Information, 2020), 'Provincial Guidelines for Greenhouse Gas Inventories(PGGGI)' (Development, 2011), 'China's Regional State Grid Average Carbon Dioxide Emission Factor for 2011-2012' (China, 2014) were used to select the coefficients and form carbon accounting methods which are most suitable for Tianjin city regions of China. Calculation of $\mathrm{CO}_{2}$ emissions, equal to the energy consumption and coefficient;

$$
E=\lambda \sum_{i=1}^{n} A_{D_{i}} \times E_{i}
$$

Where $\mathrm{E}$ represents $\mathrm{CO}_{2}$ emission due to energy consumption. i represents the corresponding energy coefficient, and $\mathrm{E}_{\mathrm{i}}$ is the emission factor.

\section{Carbon emissions accounting}

\subsection{University campus carbon emissions inventory}

Fig. 6 identifies the carbon emissions inventory which can be classified based on the emission source. The most important source is the emission from the campus buildings. Carbon emissions of buildings are composed of: the product stage, construction stage, operational stage, and the end of the life, or recycling stage. The carbon emission from the 'use' stage is mainly from its operational stage, where we conducted carbon emissions calculations in our research.

The second source of emissions is mobility. A campus can be considered as a small city, where people move regularly across the two sites as well as different logistic vehicles which provide services. Based on the users, mobility can be divided into four main parts: support staff and teaching staff, students, visitors from outside and logistics. The third source of emissions is campus life activities generating high levels of carbon emissions. The most carbon emissions can be observed from waste generation 
and people breathing inside the campus. The other factors are food and water usage inside the campus. Out of these emissions, food, waste and water could be controlled or managed more effectively. The carbon emission from people breathing inside the campus cannot be controlled, instead this could be replaced by carbon sequestration using more plantations. In summary, the campus carbon emission inventory diagram can be used as a guide 339 for calculating both campuses' carbon emissions. In this study, we calculated carbon 340 emissions through their operational stage. In later sections of this paper we will examine 341 embodied carbon, and the operational platform which will monitor, review, estimate, 342 and most importantly, demonstrate - the carbon reduction paths for colleges and 343 universities. 


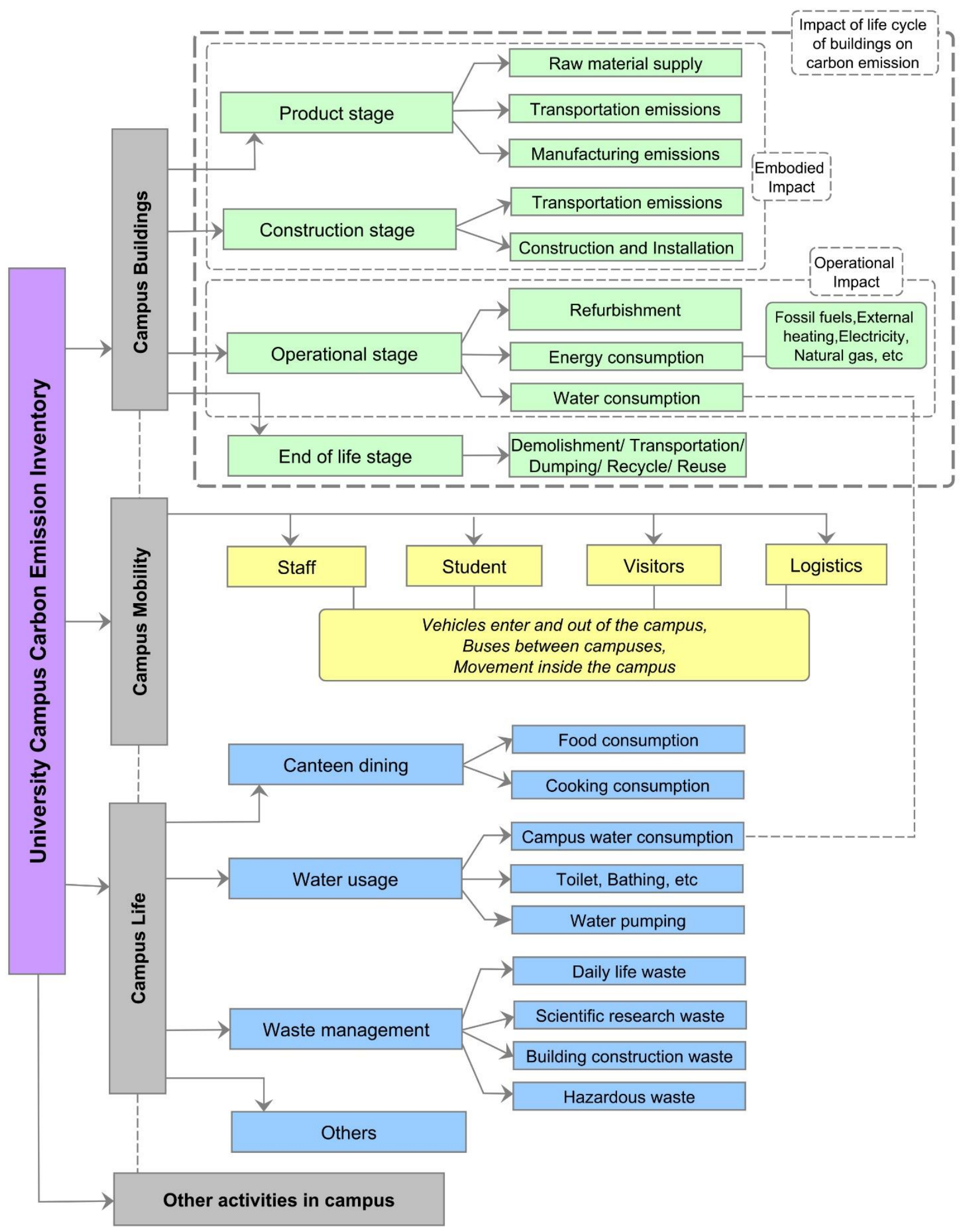

Fig. 6 Campus carbon emissions source system and classification 


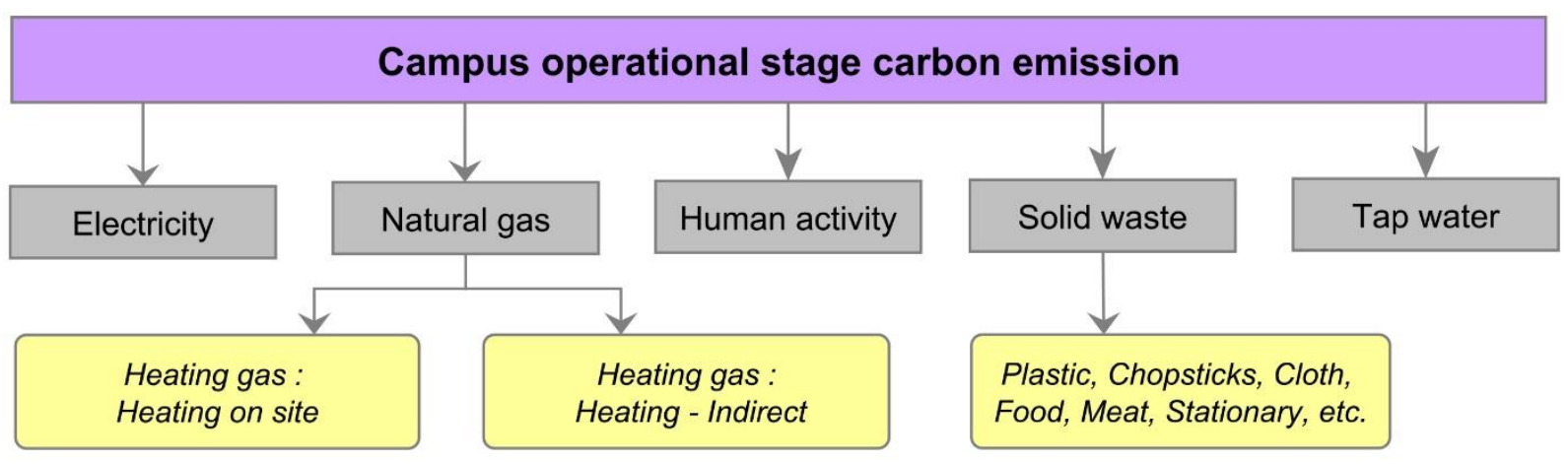

Fig. 7 Campus carbon emission calculation model based on the operational stage

\subsection{Carbon emissions of electricity usage}

The arithmetic terms of calculation are the following:

$$
E_{\text {electricity }}=\sum_{i=1}^{n} S_{i} \times I_{\text {electricity }}
$$

Where, $\mathrm{S}_{\mathrm{i}}$ is the electricity consumed by $\mathrm{i}$ buildings $(\mathrm{KWh}), \mathrm{i}$ represents the number of buildings. I electricity emission factor $\left(\mathrm{kgCO}_{2} / \mathrm{KWh}\right)$.

The electricity used in both campuses is from the China State Grid, according to China's Regional State Grid average carbon dioxide emission factor for 2011-2012, published by the National Development and Reform Commission of the People's Republic of China, Tianjin belongs to the North China Branch of the State Grid. The standard emission factor for electricity is given as $\mathrm{I}_{\text {electricity }}=0.8843 \mathrm{kgCO}^{2} / \mathrm{kWh}(\mathrm{China}$, 2014). There is no official data available for the standard emission factor for Tianjin in 2019, although the most recent research, published by academician Jiang yi, pointed out that the national average electricity carbon emission factor for 2019 is: $\mathrm{I}_{\text {electricity }}=0.577$ $\mathrm{kg} \mathrm{CO} / \mathrm{kwh}$ (Yi and Shan, 2021). So for this purpose, we use the average electricity carbon emission factor of China in 2019. 
363 And, the total carbon emission of Peiyangyuan Campus from electricity:

$364=38274.03$ tonnesCO $\mathrm{CO}_{2}$

Table 2 Carbon emissions of TJU's two campuses from electricity usage

\begin{tabular}{cc}
\hline Campus & CO$_{2}$ emission of electricity usage \\
\hline Weijin Road Campus & 35729.77 tonnes \\
Peiyangyuan Campus & 38274.03 tonnes \\
\hline
\end{tabular}

\subsection{Carbon emission by natural gas (consumption during heating)}

Natural gas data for the Weijin Road Campus is used for combustion engines and gas-fired boilers for heating Teaching Buildings No.25 and partially for the Student

Dormitory. In 2019, the total amount of natural gas consumed inside the campus is $158200 \mathrm{~m}^{3}$ (per annum).

Heating for the majority of buildings within Weijin Road campus is provided by the city municipality, using natural gas. Heating in Peiyangyuan campus is from heating appliances also using natural gas.

The arithmetic term of calculation is the following:

$$
E_{\text {natural gas }}=\sum_{i=1}^{n} S_{i} \times I_{\text {natural gas }}
$$

Where, $\mathrm{S}_{\mathrm{i}}$ natural gas used in No. i building $\left(\mathrm{m}^{3}\right)$

$\mathrm{I}_{\text {natural gas }}$ is the carbon emission caused by burning $1 \mathrm{~m}^{3}$ natural gas,

378 Natural gas measured (Tianjin area) has a calorific value of $33,486.8144 \mathrm{KJ} / \mathrm{m}^{3}$. Carbon content per unit of calorific value is $15.32 \mathrm{TC} / \mathrm{TJ}$ and carbon oxidation rate is 0.99 
(2021), so the standard emission factor for natural gas is:

$I_{\text {natural gas }}=\left(1 \times 33,486.8144 \mathrm{KJ} / \mathrm{m}^{3} \times 15.32 \mathrm{TC} / \mathrm{TJ} \times 0.99 \times 44 / 12\right) / 1000000=$ $1.862321 \mathrm{kgCO}_{2} / \mathrm{m}^{3}$.

Thus, the total carbon emission Weijin Road Campus from natural gas (for heating):

$=12060.76$ tonnes (per annum)

385 The total carbon emission for Peiyangyuan Campus from natural gas:

$=6402.47$ tonnes $($ per annum)

Table 3 Carbon emission of TJU's two campuses from natural gas usage

\begin{tabular}{cc}
\hline Campus & CO2 $_{2}$ emission of natural gas usage \\
\hline Weijin Road Campus & 12060.76 tonnes \\
Peiyangyuan Campus & 6402.47 tonnes \\
\hline
\end{tabular}

\subsection{Carbon emissions from mobility}

The mobility of vehicles within TJU is complex, as the area of the university is

large, densely populated, and generally very busy at peak times. To overcome this problem an average travelling distance inside the university was calculated based upon the entry points and parking bay locations. The travelling distance to each parking bay was calculated with the aid of Google Maps to measure optimum travel distances. Distances were carefully plotted and the average of these distances were assimilated. Entry points and parking bays for the TJU Weijin Road Campus are shown in Fig. 8. Weijin Road Campus has three main entry gates which are called East Gate, West Gate, and North Gate. All vehicles are allowed to enter from these gates.

The distance from each entry point to the most used parking bays is shown in 
distance of any vehicle inside the Weijin Road campus is $1.594 \mathrm{~km}$.

The entry points and parking bays for the TJU Peiyangyuan Campus are shown in Fig. 9. It was observed from this calculation that the average travelling distance of any vehicle inside the Peiyangyuan Campus is $2.720 \mathrm{~km}$ (Appendix B).

Data regarding vehicles entering and exiting the university campus was obtained from the Security Department of Weijin Road and Peiyangyuan Campus. Weijin Road campus during 2019 had a total count of cars entering and exiting amounting to 92964 , whereas Peiyangyuan campus had 860359 cars entering and exiting the campus.

Overall average distance travelled inside the campus:

Weijin Road Campus: $\mathrm{D}=929641 \div 2 \times 1.594 \mathrm{~km}=740923.9 \mathrm{~km}$

Peiyangyuan Campus: $\mathrm{D}=860359 \div 2 \times 2.720 \mathrm{~km}=1170088 \mathrm{~km}$

The arithmetic term of CF calculation of transportation is the following:

$$
E_{\text {transportation }}=\sum_{i=1}^{n} D_{y} \times Q_{\text {fuel consumption }} \times I_{\text {fuel consumption }} \div 100
$$

Where: $E_{\text {transportation }}$ is carbon emission, $\mathrm{D}_{\mathrm{y}}$ a car travel distance over a year $(\mathrm{km} / \mathrm{d}$. per car), $Q_{\text {fuel consumption }}$ (fuel consumption/100 km), $I_{\text {fuel consumption }}$ is the carbon dioxide emission coefficient of energy $\left(\mathrm{kgCO}_{2} / \mathrm{kg}\right)$, and $\mathrm{i}$ is the energy consumed. According to the 'Automobile Enterprises Corporation', the average fuel consumption published by the Ministry of Industry and Information Technology of the People's Republic of China, the corporate average fuel consumption is $5.56 \mathrm{~L} / 100 \mathrm{~km}$ (China, 2020).

The standard emission factor for diesel oil is given as $I_{\text {Diesel oil }}=3.096 \mathrm{kgCO}_{2} / \mathrm{kg}$, one liter of diesel is $0.9 \mathrm{~kg}$ on average (2021). 


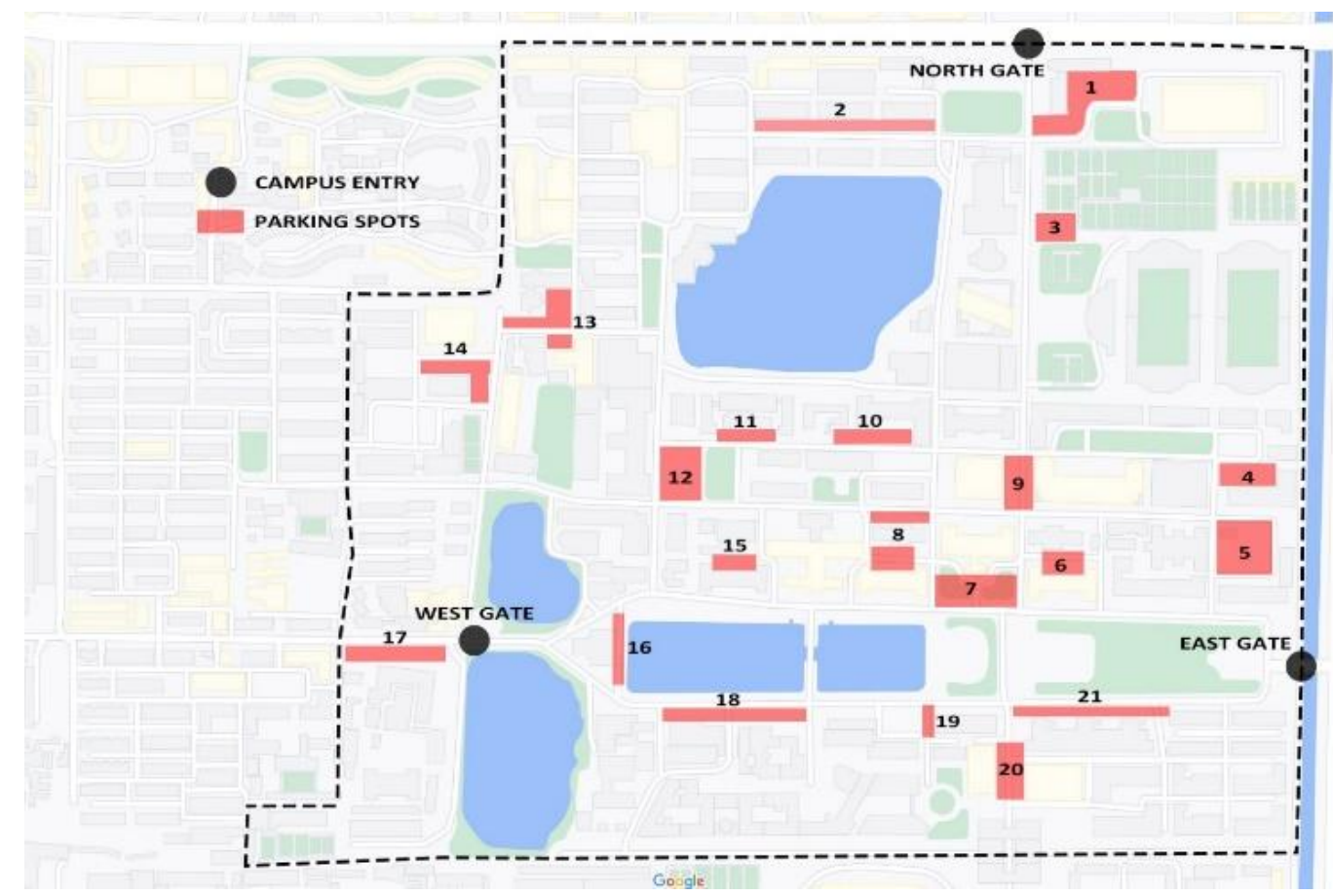

Fig. 8. Entry, exit and parking spots inside the Weijin Road Campus

\section{Weijin Road Campus:}

$423 E_{\text {transportation }}=740923.9 \mathrm{~km} \times(5.56 \times 0.9 \mathrm{~kg}) / 100 \mathrm{~km} \times 3.096 \mathrm{kgCO}_{2} / \mathrm{kg}=114.79$

424 tonnes (per annum)

$425 \quad$ Peiyangyuan Campus:

$426 E_{\text {transportation }}=1170088 \mathrm{~km} \times(5.56 \times 0.9 \mathrm{~kg}) / 100 \mathrm{~km} \times 3.096 \mathrm{kgCO} 2 / \mathrm{kg} \div 100=$

$427 \quad 181.27$ tonnes (per annum)

428 Table 4 Annual vehicles entering and exiting the campus, Note: Data obtained from the Security

429 Department of Weijin Road and Peiyangyuan Campus.

430

\begin{tabular}{ccc}
\hline Campus & $\begin{array}{c}\text { Total count of vehicles } \\
\text { enter and exit }\end{array}$ & $\begin{array}{c}\text { CO}_{2} \text { emission of the } \\
\text { vehicle }\end{array}$ \\
\hline Weijin Road Campus & 929641 & 114.79 tonnes \\
Peiyangyuan Campus & 860359 & 181.27 tonnes \\
\hline
\end{tabular}




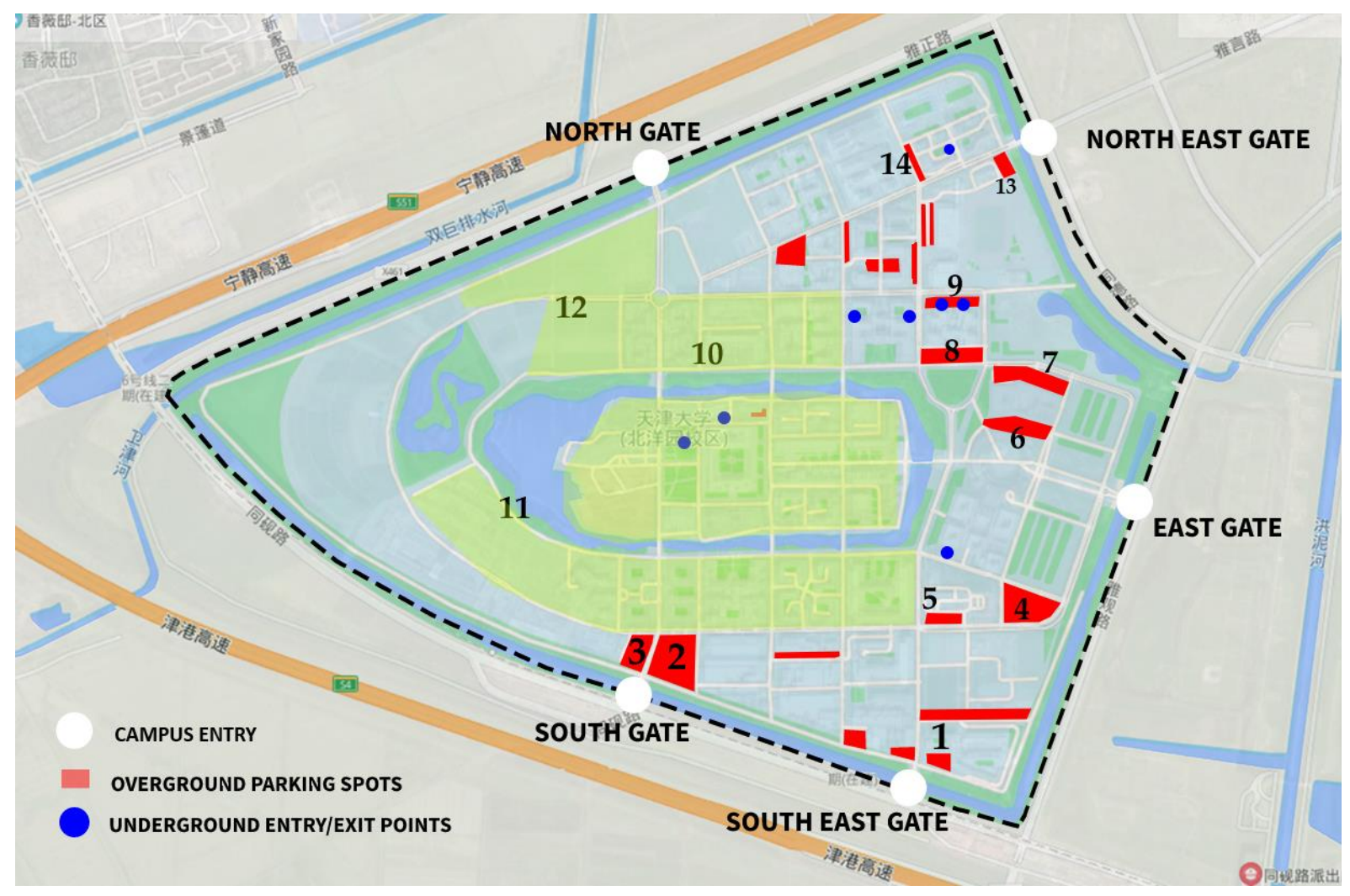

Fig. 9 Entry, exit and parking spots inside the Peiyangyuan Campus

\subsection{Carbon emission by solid waste generation}

Solid waste treatment in the Tianjin campus is by incineration. According to IPCC

$\mathrm{CO}_{2}$ emission of the total amount of waste combusted can be calculated by the equation:

$$
\mathrm{CO}_{2} \text { Emissions }=\mathrm{MSW} \times \sum_{i=1}\left(W F_{i} \times d m_{i} \times C F_{i} \times F C F_{i} \times O F_{i}\right) \times 44 / 12
$$

Where: $\mathrm{CO}_{2}$ Emissions in inventory year, tonnes/per annum;

MSW: the total amount of municipal solid waste as wet weight incinerated or open burned, tonnes/per annum,

$\mathrm{WF}_{\mathrm{j}}$ : fraction of carbon in the dry matter (total carbon content),

$\mathrm{dm}_{\mathrm{j}}$ : dry matter content in the component $\mathrm{i}$ of the MSW incinerated or openburned, (fraction)

$\mathrm{CF}_{\mathrm{j}}$ : fraction of carbon in the dry matter 
$\mathrm{FCF}_{\mathrm{j}}$ : fraction of waste type/material of component $\mathrm{i}$ in the MSW( as wet weight incinerated or open-burned) waste generated.

Peiyangyuan Campus waste generation per day is about 35 tonnes (after dehydration). Therefore, the total waste during the year $=$ during school day + during vacation $(292 \times 35 t)+(73 \times 35 \times 1 / 4)=10858.75$ tonnes

Therefore total MSW peiyangyuan $=10858.75$ tonnes .

Peiyangyuan Campus: $\mathrm{CO}_{2}$ emissions from solid waste $=10858.75 \times 0.20 \times 0.39$ $\times 0.95 \times 44 / 12=2950.32$ tonnes.

Weijin Road campus solid waste is managed by the Tianjin City Municipality and it is not clear how much waste is generated on campus each day or per annum. An average per capita solid waste generation for Peiyangyuan Campus was estimated and used to calculate the Weijin Road Campus carbon emission from solid waste.

Total waste generated during the year in Weijin Road campus $=($ Total waste in Peiyangyuan Campus/Total population in Peiyangyuan) $\times$ Total population in Weijin Road Campus $=(10858.75 / 22488) \times 22363=10798.39$ tonnes. 
Weijin Road Campus: $\mathrm{CO}_{2}$ emissions from solid waste $=10798.39 \times 0.95 \times 0.20$

465

466

467

468

469

470

471

472

473

474

475

476

477

478

479

480

481

482

$\times 0.39 \times 44 / 12=2933.92$ tonnes.

\subsection{Faculties and students' daily life consumption}

The emission caused by faculties, students, and other nonacademic staff on campus is difficult to assess, so approximate values were derived from similar situations. The most recent study on carbon emission caused by human activity is from Peking University. In this study, it was estimated that daily consumption of plastic, chopsticks, cloth, food, meat, buying a book, and paper, etc. created an average of 0.53 tonnes/per person per annum, so during the academic year of 292 days, the average was 0.39 tonnes/per person per academic year (Y Zheng, 2011).

$$
E_{\text {daily life }}=C_{D A Y} \times R \times t
$$

Where, $\mathrm{C}_{\mathrm{i}}$ per capita carbon emission per day, $\mathrm{R}$ total population of campus, $\mathrm{t}$ number of days for calculation.

Weijin Road Campus $=6977.26$ tonnes;

Peiyangyuan Campus $=7016.26$ tonnes

Table 5 Carbon emission of TJU's two campuses from human activity

\begin{tabular}{ccc}
\hline Campus & Total population & $\mathbf{C O}_{2}$ emission of human activity \\
\hline Weijin Road Campus & 22363 & 6977.26 tonnes \\
Peiyangyuan Campus & 22488 & 7016.26 tonnes \\
\hline
\end{tabular}

\subsection{Carbon emission by tap water}

The arithmetic term of Carbon footprint calculation of tap water is the following:

$$
E_{\text {water }}=\sum_{i=1}^{n} S_{i} \times I_{\text {water }}
$$


Where $S_{\mathrm{i}}$ is water used by i buildings $\left(\mathrm{m}^{3}\right)$, i represents the number of buildings.

484

485

486

487

488

489

490

491

492

493

494

(Com, 2015).

$$
\mathrm{I}_{\text {water }} \text { emission factor }\left(\mathrm{kgCO}_{2} / \mathrm{m}^{3}\right)
$$

Tap water consumption is considered with a conversion factor of $0.194 \mathrm{kgCO}_{2} / \mathrm{m}^{3}$

\author{
(Com, 2015).
}

Weijin Road Campus: $E_{\text {water }}=356.18$ tonnes

Peiyangyuan Campus: $E_{\text {water }}=389.40$ tonnes

Table 6 Carbon emission caused by using tap water for consumption

\begin{tabular}{cc}
\hline Campus & CO$_{2}$ emission of tap water usage \\
\hline Weijin Road Campus & 356.18 tonnes \\
Peiyangyuan Campus & 389.40 tonnes \\
\hline
\end{tabular}

\title{
4.10 Total Carbon emission
}

The total Weijin Road Campus emission for 2019

$\mathbf{E}($ Total $)=\mathrm{E}($ electricity $)+\mathrm{E}($ natural gas $)+\mathrm{E}($ transportation $)+\mathrm{E}($ solid waste $)+\mathrm{E}($ tap

water $)+E($ human activity)

Table 7 TJU Weijin Road Campus - Fiscal Year 2019 emissions and percentages

\begin{tabular}{lcc}
\hline Item & Emissions (tonnes $\left.\mathbf{C O}_{2}\right)$ & Percentage \\
\hline Purchased electricity & 35729.77 & 61.42 \\
Natural gas for heating & 12060.76 & 20.73 \\
Human activity & 6977.26 & 11.99 \\
Solid waste & 2933.92 & 5.04 \\
Tap water & 356.18 & 0.61 \\
Transportation & 114.79 & 0.20 \\
Total Carbon emission & $\mathbf{5 8 1 7 2 . 6 8}$ & $\mathbf{1 0 0 \%}$ \\
\hline
\end{tabular}




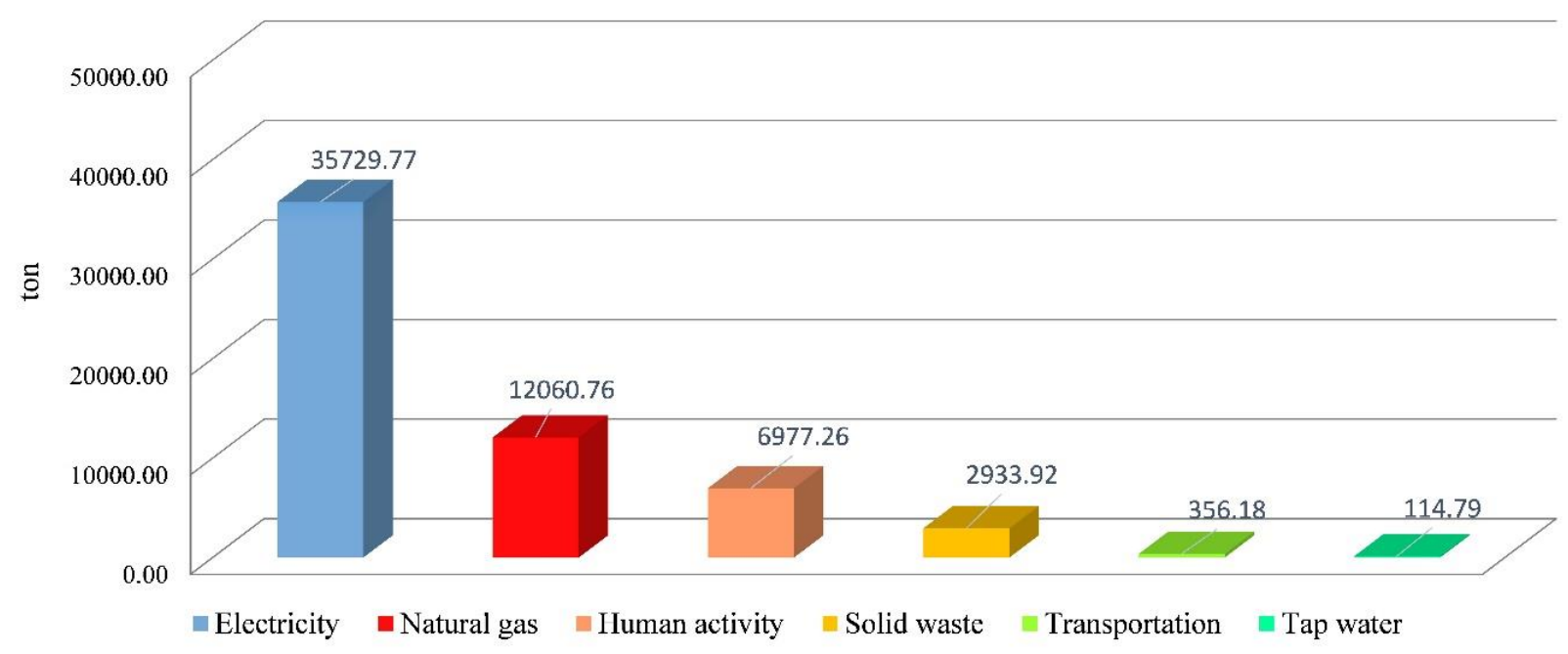

Fig. 11 Carbon footprint by source at Weijin Road Campus

495 Table 8 TJU Peiyangyuan Campus's- the Fiscal Year 2019 emissions and percentages

\begin{tabular}{ccc}
\hline Item & Emissions (tonnes CO2) & Percentage \% \\
\hline Purchased electricity & 38274.03 & 69.32 \\
Natural gas for heating & 6402.47 & 11.60 \\
Human activity & 7016.26 & 12.71 \\
Solid waste & 2950.32 & 5.34 \\
Tap water & 389.40 & 0.71 \\
Transportation & 181.27 & 0.33 \\
Total & $\mathbf{5 5 2 1 3 . 7 5}$ & $\mathbf{1 0 0 \%}$ \\
\hline
\end{tabular}

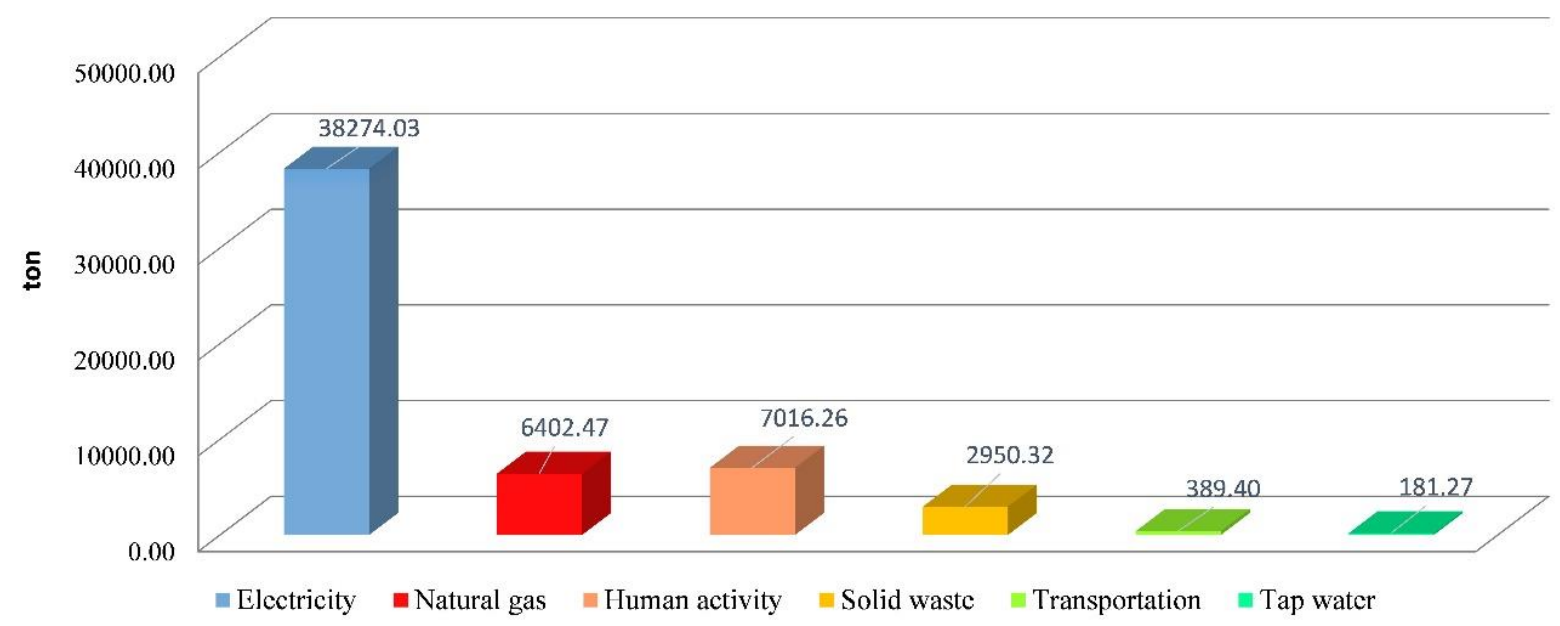

Fig. 10 Carbon footprint by source at Peiyangyuan Campus 


\subsection{Total carbon sequestered amount by trees and green areas}

The intensity of green plant photosynthesis and the plant's leaf area is critical for carbon sequestration. To account for the carbon sequestration of green plants on campus, the green-lands type structure on campus is divided into four types: tree-shrub-herb type, shrub-herb type, lawn type, and grassland.

The arithmetic term of carbon sequestration amount is the following:

$$
C_{\text {sequestration }}=\sum_{i=1}^{n} T_{i} \times S_{i} \times D
$$

Where $T_{i}$ is $i$ are green-lands with daily carbon sequestration $\left(\mathrm{g} \cdot \mathrm{m}^{-2} \cdot \mathrm{d}^{-1}\right)$

$S_{i}$ and $i$ area green-lands area $\left(\mathrm{m}^{2}\right)$; D number of days for calculation, generally $\mathrm{D}=365$.

Weijin Road Campus: the lawn area is approximately $153700 \mathrm{~m}^{2}$ and there are 15,000 trees and shrubs.

$$
C_{\text {lawn }}=153700 \mathrm{~m}^{2} \times 55.42 \mathrm{~g} \cdot \mathrm{m}^{-2} \cdot \mathrm{d}^{-1} \times 365=3109.09 \text { tonnes }
$$

The available published report regarding Weijin Road campus's carbon sequestration suggests that $1,950 \mathrm{~m}^{2}$ area with 50 tree-shrub-herb types or shrub-herb, have total average carbon sequestration of approximately 27.16 tonnes (Garden, 2021);

$$
\mathrm{C}_{\text {trees and bush }}=(\text { Total tree }- \text { shrub }- \text { herb type shrub }- \text { herb }) / \text { unite carbon sample area }
$$
total tree-shrub-herb $\times 27.16$ tonnes $=8148.25$ tonnes

$$
\text { Therefore, the total carbon sequestration of the Weijin Road Campus is: }
$$

$$
C_{\text {lawn }}+\mathrm{C}_{\text {trees }} \text { and bushes }=11257.34 \text { tonnes }
$$

Peiyangyuan Campus: the lawn area is about $808,750 \mathrm{~m}^{2}$, there are 110 types of trees making a total of 59,740 trees inside the campus.

$$
C_{\text {lawn }}=\left(808,750 \mathrm{~m}^{2} / 2 \times 55.42 \mathrm{~g} \cdot \mathrm{m}-2 \cdot \mathrm{d}-1 \times 365\right)+\left(808,750 \mathrm{~m}^{2} / 2 \times 23.38 \mathrm{~g} \cdot \mathrm{m}-\right.
$$


$\mathrm{C}_{\text {trees and bushes }}=($ Totaltree-shrub-herb type shrub-herb $) /$ Unite carbon sample area

520

521

522

523

524

525

526

527

528

529

530

531

532

533

total tree-shrub-herb $\times 27.16 / 2$ tonnes $=16225.88$ tonnes

The total carbon sequestration of Peiyangyuan Campus is: $C_{\text {lawn }}+\mathrm{C}_{\text {trees }}$ and bushes $=$ 27856.51 tonnes.

Table 9 Different kinds of green-lands and types of plant structure per unit area for daily carbon sequestration amount $\left(\mathrm{g} \cdot \mathrm{m}^{-2} \cdot \mathrm{d}^{-1}\right)($ GUO Xinxiang, 2010)

\begin{tabular}{lcccc}
\hline \multicolumn{1}{c}{ Type } & tree & bush & lawn & Total \\
\hline $\begin{array}{l}\text { tree-shrub- } \\
\text { herb type }\end{array}$ & 35.67 & 20.95 & 23.38 & 79.99 \\
\hline shrub-herb & 15.29 & 33.52 & 23.38 & 72.18 \\
\hline lawn & 15.29 & 16.67 & 23.38 & 55.42 \\
\hline grassland & 0.00 & 0.00 & 23.38 & 23.38 \\
\hline
\end{tabular}

\subsection{Carbon emissions reduction by renewable energy}

\subsubsection{Solar water heater}

Weijin Road Campus has no renewable energy at the moment, whereas, on Peiyangyuan Campus there are solar water heaters, ground source heat pumps and air source heat pumps in use.

According to the design specification, Peiyangyuan Campus solar water heater system's design terms are: water temperature should be considered $60^{\circ} \mathrm{C}$, and the winter temperature of tap water set at $10^{\circ} \mathrm{C}$. Total water consumed during 2019 at 3387.20 tonnes $=(11.69$ tons per day $\times 292$ school day $)$, with solar fraction factor being $60 \%$.

Total heat absorbed: $\mathrm{Q}=\mathrm{C}_{\mathrm{p}} \mathrm{m} \Delta \mathrm{T}=4.18 \times 3387200 \times(60-10)=0.71 \times 10^{12} \mathrm{~J}$.

Where: $\mathrm{Q}$ is heat absorbed, $\mathrm{C}_{\mathrm{p}}$ is the specific heat capacity of liquid water $\left(\mathrm{C}_{\mathrm{p}}=4.18 \mathrm{KJ} / \mathrm{kg} \cdot{ }^{\circ} \mathrm{C}\right), \mathrm{m}$ is mass of water, $\Delta \mathrm{T}$ is the change in temperature, defined as 
the difference between the final temperature and the initial temperature.

$$
Q^{\prime}=Q \times 60 \%=0.71 \times 10^{12} \mathrm{~J} \times 60 \%=0.43 \times 10^{12} \mathrm{~J}
$$

Carbon emission coefficient of standard coal $94.60 \mathrm{t} / \mathrm{TJ}$, and the efficiency of $\eta$

boiler $=80 \%$. So the amount of carbon reduction by the solar water heater, $\mathrm{BE}=(0.43 \times$ $\left.10^{12} \div 80 \%\right) \times 94.60 \mathrm{t} / \mathrm{TJ} \times 10^{-12}=50.85$ tonnes

Therefore, the total avoided greenhouse gas emission due to using a solar water heater system is 50.85 tonnes.

\subsection{Carbon neutrality assessment}

$$
E_{n e t}=E(\text { total })-E(\text { sequestered })-\text { carbon reduction by renewable energy }
$$

Table 10 Carbon neutrality assessment

\begin{tabular}{ccccc}
\hline Campus & $\begin{array}{c}\text { Total carbon } \\
\text { emission } \\
\text { (tonnes) }\end{array}$ & $\begin{array}{c}\text { Total carbon } \\
\text { Sequester } \\
\text { (tonnes) }\end{array}$ & $\begin{array}{c}\text { Carbon reduction } \\
\text { by renewable energy } \\
\text { (tonnes) }\end{array}$ & $\begin{array}{c}\text { Net carbon } \\
\text { emission } \\
\text { (tonnes) }\end{array}$ \\
\hline $\begin{array}{c}\text { Weijin Road } \\
\text { Campus }\end{array}$ & 58172.68 & 11257.34 & - & 46915.34 \\
\hline $\begin{array}{c}\text { Peiyangyuan } \\
\text { Campus }\end{array}$ & 55213.75 & 27856.51 & 50.85 & 27357.23 \\
\hline
\end{tabular}

\section{Results comparison analysis}

\subsection{Comparison of the two campuses}

According to the 2019 inventory, Tianjin University's two campuses emitted 113,386.42 metric tons of carbon dioxide equivalent. Fig. 10 shows that, at Tianjin University's both campuses, electricity was the greatest source of emission, producing $65.27 \%$ of total carbon emission followed by natural gas for heating, producing $16.28 \%$, human activity producing $12.34 \%$, solid waste generation producing $5.19 \%$, tap water and transportation producing $0.66 \%$ and $0.26 \%$ respectively (Fig. 12). 


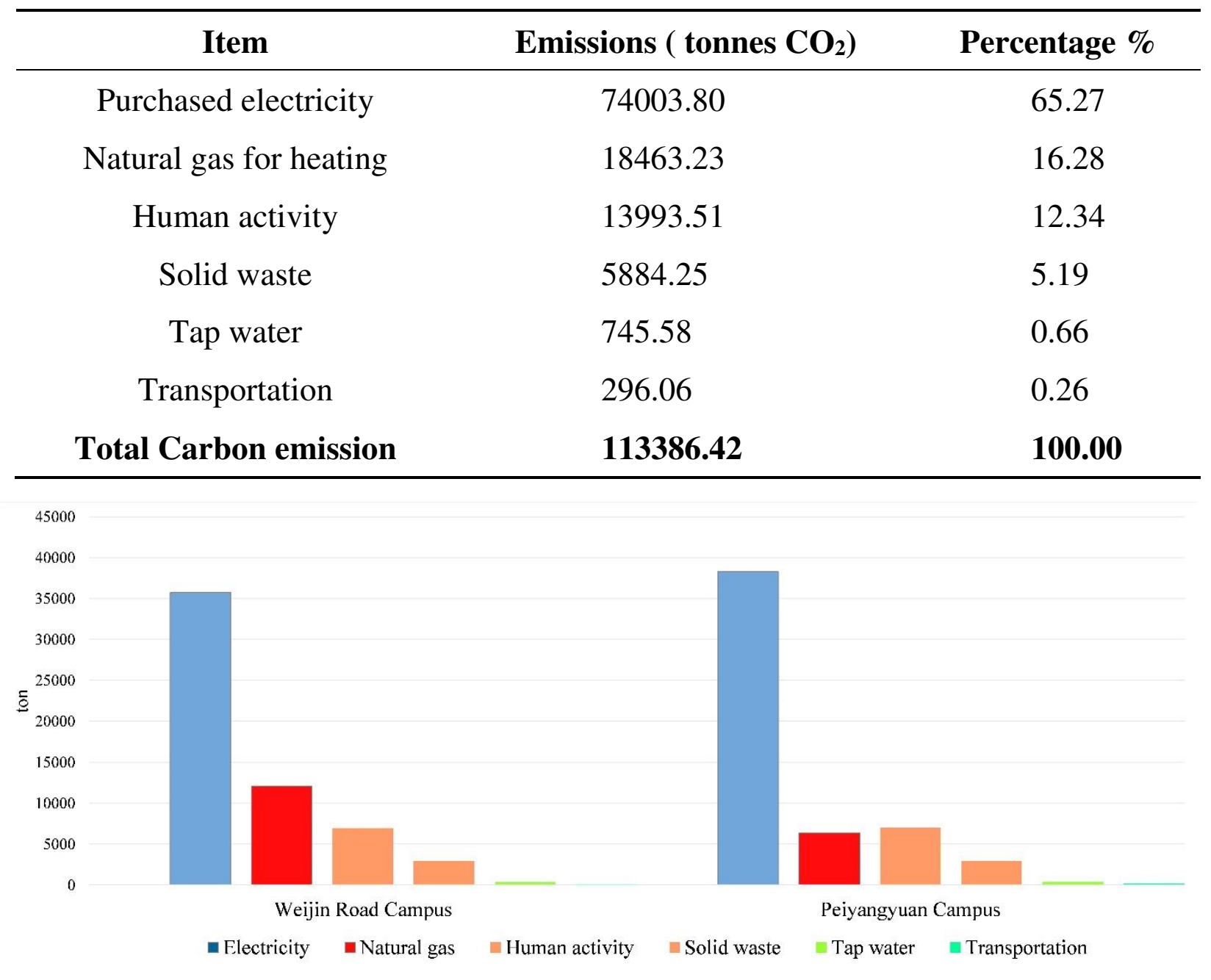

Fig. 12. Carbon emissions percentage by sector

Results show that the campus's emissions are mostly concentrated on a daily 'operational stage'. Most of the energy use is heating related to the winter season,

558 followed by air conditioning, lighting, and canteen cooking, affecting $\mathrm{CO}_{2}$ campus 559 emissions. The majority of energy consumed on both campuses is electricity, and natural 560 gas, constituting $81.55 \%$ (Fig. 13) of total carbon emission with electricity usage being 561 highest on both campuses. The main difference in carbon emissions is natural gas usage.

562 Weijin Road Campus uses heat provided by the Municipal Corporation of Tianjin, 563 whereas Peiyangyuan Campus produces heating on its own. Carbon emissions from 
transportation in both campuses are very low and this could be reduced in the future by

565

566

567

568

569

570

571

572

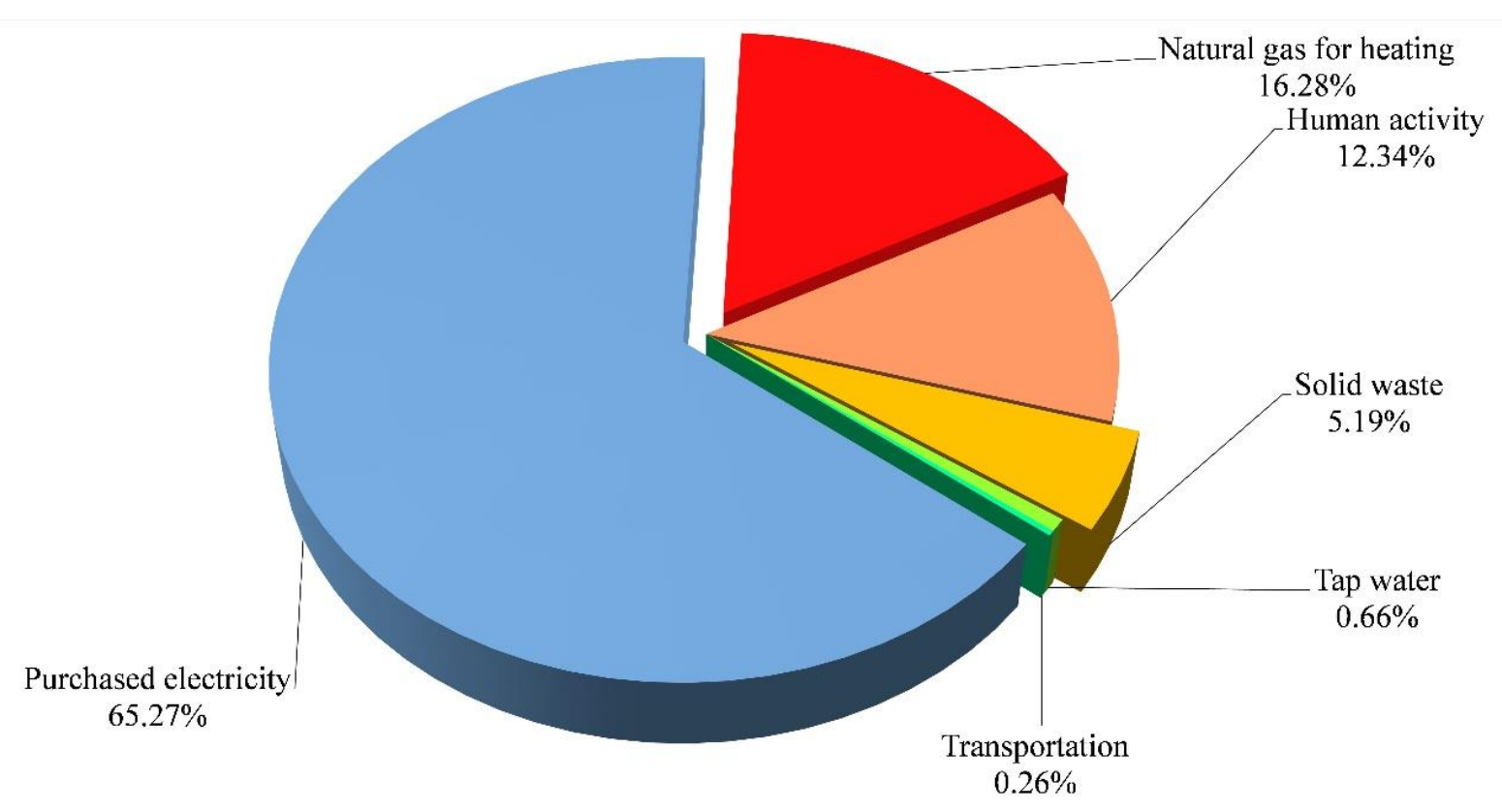

Fig. 13 Carbon emission percentage by sector

\subsection{General comparison with other campuses around the world}

This section outlines the comparison between carbon emissions from different

universities around the world using at least two universities from each continent. There were many universities from Europe and USA but only one university from Africa and South America, where current research data was available. In total, 13 Universities were 
576 selected as shown in Table 12 , together with Tianjin University. For this comparison, 577 both campuses were combined to represent Tianjin University as a whole.

578 The survey started with analyzing published research papers regarding the carbon 579 emissions of universities around the world. Only specific data was used for each 580 university so that all universities can be compared within the same parameters together 581 with scientific papers and university reports. It wasn't possible to collate data for the 582 same year as each university had research or publications carried out in different years 583 and therefore data is presented from universities not older than 2013. The total number 584 of students and staff was directly adopted with $\mathrm{CO}_{2}$ emissions taken from existing 585 research papers and university reports. The carbon footprint of each university is further 586 evaluated based upon two main factors, per capita and per build-up area. The term 'Build 587 Up Enclosure Area' is used as a common term to describe the different areas under 588 consideration while calculating carbon emissions. These areas differ between 589 universities as they use alternative units such as: measuring internal net floor areas, 590 deducting lift shafts, vertical service shafts, stairs, etc. In this study, it is assumed under 591 the same collective term for general comparison. 
Table 12 Universities around the world and their carbon emissions (Note: data a \& b

593 taken from 2017 Zhejiang university yearbook)

\begin{tabular}{|c|c|c|c|c|c|c|c|}
\hline NO & $\begin{array}{c}\text { University } \\
\text { (Or campus) }\end{array}$ & Country & $\begin{array}{c}\text { Research } \\
\text { period }\end{array}$ & $\begin{array}{l}\text { Total No. } \\
\text { of students } \\
\text { and staff }\end{array}$ & $\begin{array}{c}\text { Build up } \\
\text { enclosure } \\
\text { areas }\left(\mathbf{m}_{2}\right)\end{array}$ & $\begin{array}{c}\text { Tonnes } \mathrm{CO}_{2} \mathrm{e} \\
\text { emitted / per } \\
\text { annum }\end{array}$ & Ref \\
\hline 1 & $\begin{array}{l}\text { Tianjin } \\
\text { University }\end{array}$ & China & 2019 & 46269 & $3,798,000$ & $113,386.42$ & $\begin{array}{l}\text { (University, } \\
\text { 2020b) }\end{array}$ \\
\hline 2 & $\begin{array}{l}\text { Tongji } \\
\text { University }\end{array}$ & China & 2014 & 53000 & $1,600,000$ & 180,480 & $\begin{array}{c}\text { (Li et al., } \\
2015)\end{array}$ \\
\hline 3 & $\begin{array}{l}\text { Zhejiang } \\
\text { University }\end{array}$ & China & 2016 & $57185^{a}$ & $4,265,653^{\mathbf{b}}$ & $\begin{array}{c}\text { 76,649.99(Zhu et } \\
\text { al., 2021) }\end{array}$ & \\
\hline 4 & $\begin{array}{c}\text { Shandong } \\
\text { Jianzhu } \\
\text { University }\end{array}$ & China & 2015 & 27622 & $1,600,000$ & 36798 & $\begin{array}{c}\text { (Chen Yue, } \\
\text { 2016) }\end{array}$ \\
\hline 5 & $\begin{array}{c}\text { NTU } \\
\text { Singapore }\end{array}$ & Singapore & 2017 & 40750 & $1,382,388$ & 138,402 & (NTU, 2017) \\
\hline 6 & $\begin{array}{c}\text { Yale } \\
\text { University }\end{array}$ & USA & 2016 & 28642 & $1,342,297$ & 234,024 & $\begin{array}{l}\text { (University, } \\
\text { 2016) }\end{array}$ \\
\hline 7 & $\begin{array}{c}\text { Minnesota } \\
\text { State } \\
\text { University }\end{array}$ & USA & 2017 & 15567 & 157,930 & 44,831 & $\begin{array}{l}\text { (UNIVERSI } \\
\text { TY, 2019) }\end{array}$ \\
\hline 8 & $\begin{array}{l}\text { Monash } \\
\text { University }\end{array}$ & Australia & 2015 & 70924 & 728,193 & 188,416 & $\begin{array}{l}\text { (University, } \\
\text { 2016) }\end{array}$ \\
\hline 9 & $\begin{array}{l}\text { University of } \\
\text { Queensland }\end{array}$ & Australia & 2015 & 57621 & 747,523 & 214,249 & $\begin{array}{l}\text { (QUEENSL } \\
\text { AND, 2015) }\end{array}$ \\
\hline 10 & $\begin{array}{l}\text { Leuphana } \\
\text { University }\end{array}$ & Germany & 2015 & 10339 & 83,300 & 7,593 & 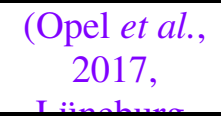 \\
\hline 11 & $\begin{array}{l}\text { Kings College, } \\
\text { London }\end{array}$ & $\begin{array}{l}\text { Great } \\
\text { Britain }\end{array}$ & 2018 & 39877 & 251,154 & 50,556 & $\begin{array}{l}\text { (London, } \\
2020)\end{array}$ \\
\hline 12 & $\begin{array}{l}\text { University of } \\
\text { Cape Town }\end{array}$ & RSA & 2013 & 31041 & 668,165 & 88,752 & 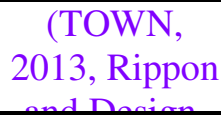 \\
\hline 13 & $\begin{array}{c}\text { University of } \\
\text { Talca }\end{array}$ & Chile & 2016 & 7869 & 98,000 & 32,869 & $\begin{array}{c}\text { (Yañez et al., } \\
\text { 2020b) }\end{array}$ \\
\hline
\end{tabular}

Intercorrelations of carbon footprints were investigated between all the universities

based upon per square meter of carbon emissions and carbon emissions per person.

Based on the data from the previous table these two factors were calculated and placed

in the chart shown in Fig14 .. It can be seen that TJU carbon emissions are lower in

comparison to most of the selected universities around the world. As the campus area of

599 TJU is very large, it accounts for less carbon emission per square meter, but 
600

601

602

603

604

605

606

607

608

2021.09.24 15:06:58). Thus the carbon footprint per USD1000 is $134.25 \mathrm{kgCO}_{2} \mathrm{e}$.

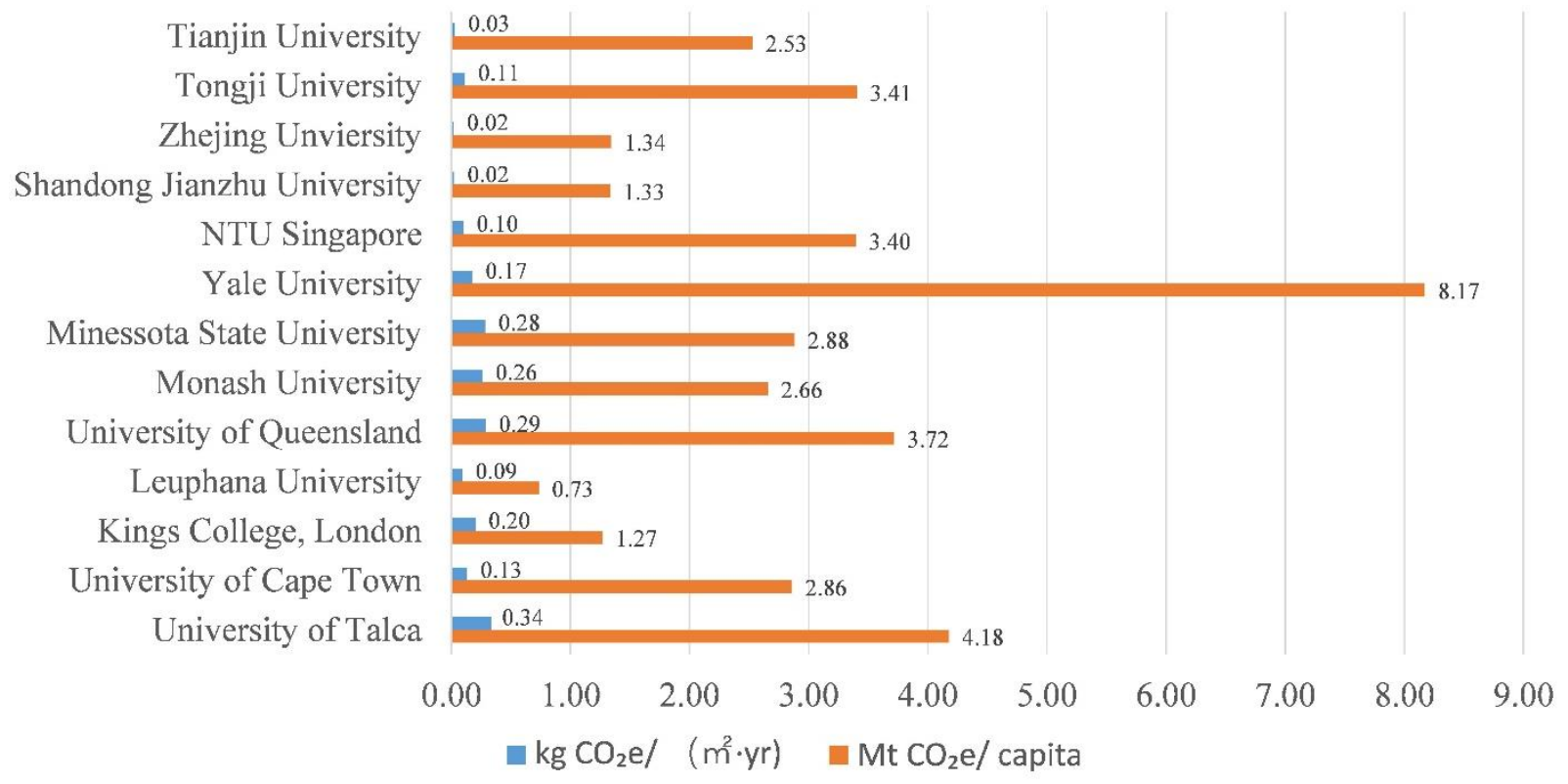

Fig .14Carbon footprints comparing universities around the world

\section{Carbon neutrality 'Road Map' for Weijin Road and Peiyangyuan}

\section{Campus}

A hypothetical carbon reduction 'Road Map' can now be proposed. The first

612 proposal is a carbon reduction plan for every each year until the total emission is zero. 
614 for the next five years until the total emission is zero.

\subsection{Time planning of carbon reduction target}

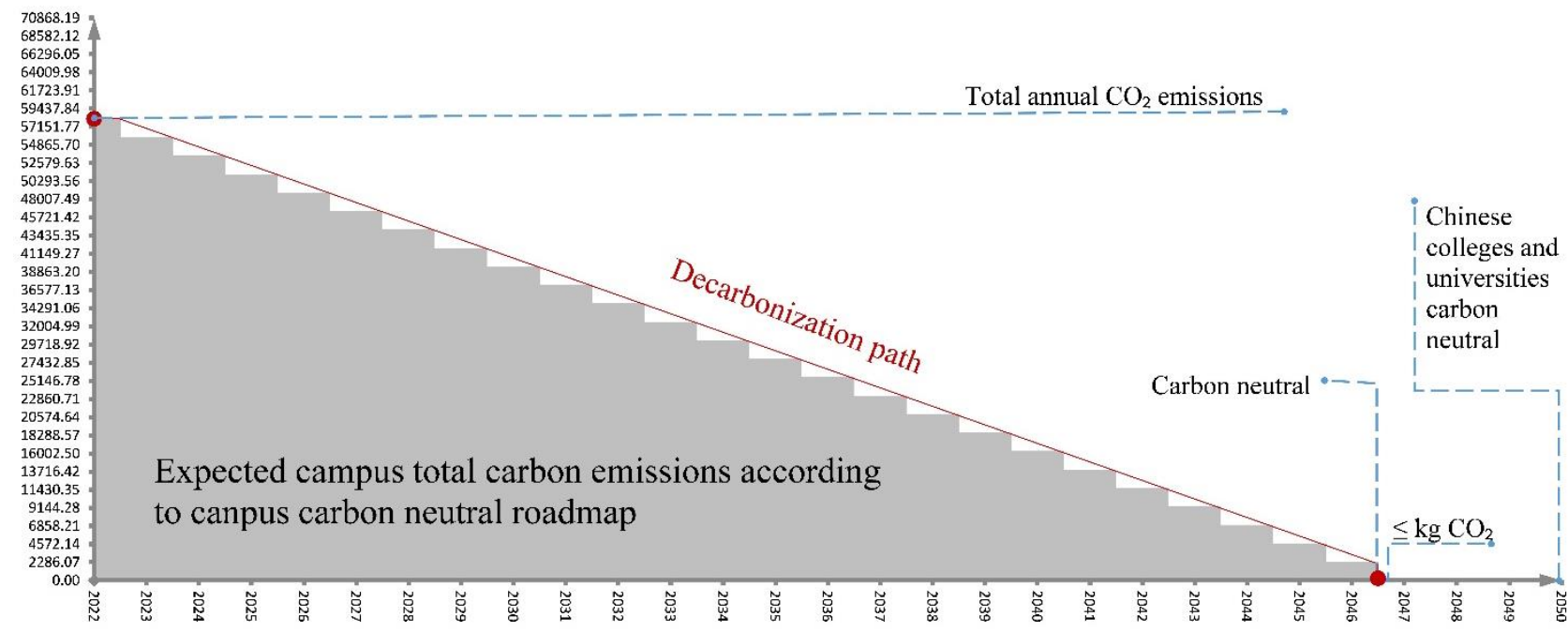

Fig. 15 Decarbonisation path for Weijin Road campus on a yearly based plan

Yearly Carbon Reduction Plan: Fig. 15 shows a carbon reduction strategy up to

617 the year 2050. This path explains one possible direction for carbon reduction over a long carbon neutrality in 2047.

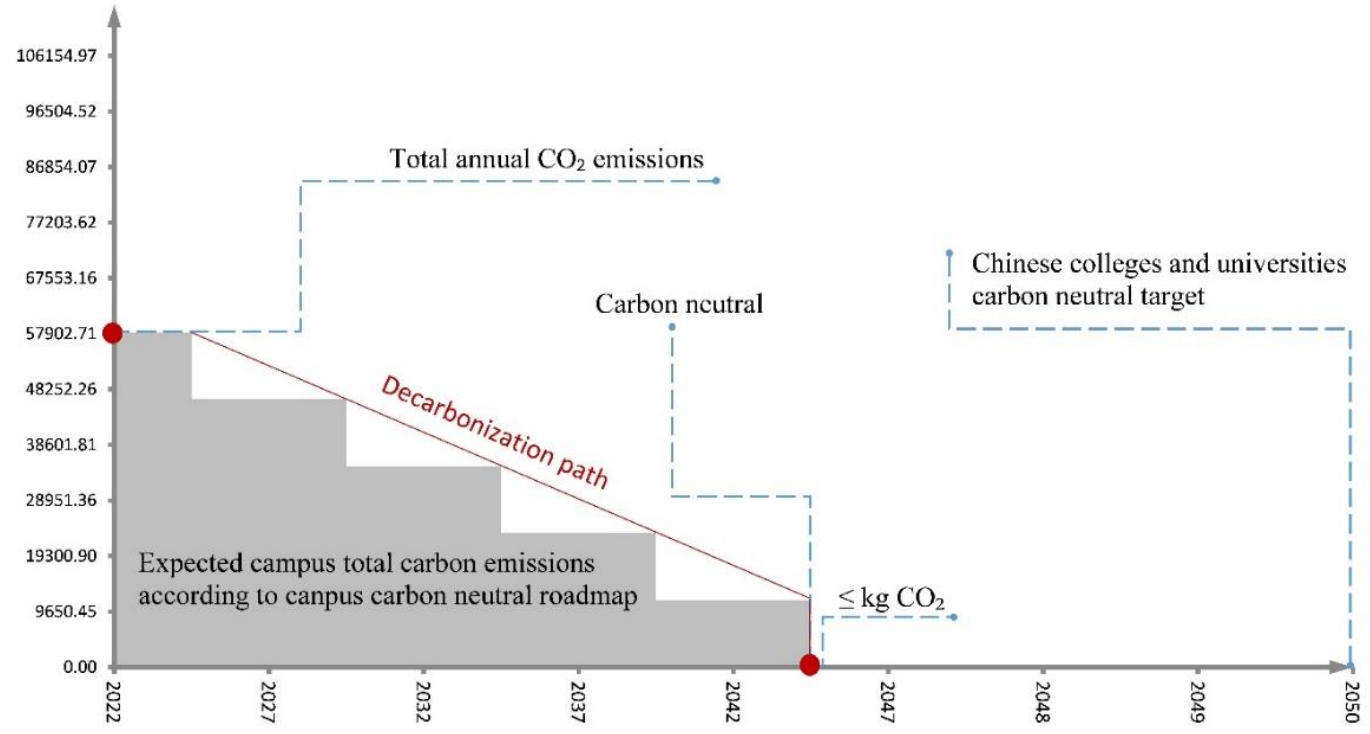

Fig. 16 Decarbonisation path for Weijin Road Campus five-yearly based plan 
Five Year carbon reduction plan: Fig. 16 shows how a series of targets need to be

621

622

623

624

625

626

627

628

629

630

631

632

633

634

635

636

achieved in successive five yearly stages to achieve zero carbon emission in the target

year of 11634.54 tonnes $\mathrm{CO}_{2}$ should be reduced each and every five years to achieve carbon neutrality in 2047 . The carbon reduction roadmap formulas are listed as below:

$\mathrm{B} 2=(\$ \mathrm{~A} \$ \mathrm{~N}-\mathrm{A} 2)^{*} \mathrm{ABS}(\mathrm{SLOPE}(\$ \mathrm{D} \$ 2: \$ \mathrm{D} \$ 3, \$ C \$ 2: \$ C \$ 3)$ ) (formula reference for Excel based Table 13)

$\mathrm{X}$ - Initial total carbon emission;

$\mathrm{N}-$ Final net zero carbon target year;

$\mathrm{T}$ - Target year of net-zero carbon emission;

E- Annual carbon reduction amount

Table 13 Campus annual carbon emission reduction amount calculating tool

\begin{tabular}{|c|c|c|c|c|c|}
\hline & $\mathbf{A}$ & $\mathbf{B}$ & $\mathbf{C}$ & $\mathbf{D}$ & $\mathbf{E}$ \\
\hline 1 & Year & $\begin{array}{c}\text { Carbon emission in the } \\
\text { corresponding year }\end{array}$ & Year & $\begin{array}{c}\text { Initial total } \\
\text { carbon emission }\end{array}$ & $\begin{array}{c}\text { Annual carbon } \\
\text { reduction } \\
\text { amount }\end{array}$ \\
\hline 2 & 2022 & & 2022 & $\mathrm{X}$ & \multirow{2}{*}{$?$} \\
\hline 3 & 2023 & & $\mathrm{~T}$ & 0 & \multirow{2}{*}{} \\
\cline { 1 - 4 }$\ldots$ & $\ldots$ & & & & \\
\hline $\mathrm{N}$ & $\mathrm{T}$ & & & & \\
\hline
\end{tabular}

\section{Limitations of this research}

- Eating routines of students and staff are variable, throughout the year, where up to three meals per day are consumed on the premises per person. Eating off-site is an unknown variable and therefore not included in this study.

- Sequestration of trees and green spaces lacks detailed onsite information where there are no standards currently available to accurately calculate sequestration of trees 
and green spaces. This study has therefore taken an average minimum, which in the future needs to be calculated more precisely and objectively.

- Since $Q_{\text {fuel consumption }}$ (fuel consumption/100 km) is closely related to vehicles type, model (such as Audi, BMW...etc.), and age. We don't have this specific and detailed information regarding vehicle types, models and age for carrying out emission calculations for transportation, but there is official data on the total number of cars entering and leaving the site. Therefore in this study for $Q_{\text {fuel consumption }}$ (fuel consumption/100 km), we have taken a corporate average for fuel consumption, which is $5.56 \mathrm{~L} / 100 \mathrm{~km}$ but in reality, $Q_{\text {fuel consumption }}$ (fuel consumption/100 km) could be higher than $5.56 \mathrm{~L} / 100 \mathrm{~km}$.

- Studies have shown that university carbon footprint from food is large, as a study from the campus cafeteria in Peking University shows. There is a necessity for further studies in the future on how best to reduce canteen carbon / ecological footprints and their emissions from daily food consumption and canteen practices (HUANG Bowei, 2016).

\section{Conclusions}

China has set a "30-60" target (China Plus, 2020), but there are still no official standards or technical guides for colleges and universities to plan for 'carbon emissions accounting and evaluation standards' (Zhu and Dewancker, 2021). The Assessment Standard for the green campus-GB/T 51356-2019' in China lacks comprehensive carbon assessment indicators, which in turn, currently constrains colleges' and universities' plans toward achieving carbon-neutral campuses. This study has laid out detailed accounting steps for a carbon footprint calculation methodology and outlined a scope of 
carbon accounting in an attempt to bring assessment theory and practice much closer together. This methodology may be used as a guide or framework for other Chinese 662 colleges and universities to establish their carbon inventory and to assist in their future 663 planning for a roadmap towards a carbon-neutral campus.

664 At present, fossil fuels still supply 84\% of world energy (Plc, 2021). Carbon 665 neutrality is a huge challenge for everyone. It is ultimately in everyone's best interest, 666 and colleges and universities must set an example and should lead this new era of 667 evolution. 
668 Abbreviations

669 Tianjin University: TJU;

670 Ethics approval and consent to participate

671 Not applicable

672 Consent for publication

673 All the authors have approved the contents of this manuscript and have all agreed to 674 submit it to Environmental Sciences Europe. All the authors confirm that the work 675 described has not been published by any academic papers or in any form of a thesis and 676 also is not under consideration for publication in any other Journals.

677 Availability of data and material

678 Datasets supporting the research included area in Appendix.

679 Competing interests

680 The authors declare no conflicts of interest.

681 Funding

682 This work was supported by the National Natural Science Foundation of China, $683(52078325,2020)$

684 Author Contributions

685 Conceived the original idea, conceptualization, writing original draft preparation, 686 investigation collected all the data and analyzed the data A.Z; Methodology—review 687 and editing by A.Z.; Formal analysis by A.Z.; writing-review, editing and visualization, 688 A.Z. and A.B.G; project administration, A.Z.; K.S. supervised and reviewed all work 
689

690

691

692

693

694

695

696

697

698

699

700

701

702

703

704

705

706

and manuscripts. Funding acquisition, A.Z. and K.S. All authors have read and agreed to the published version of the manuscript.

\section{Acknowledgements}

The author would like to acknowledge Chen Tian, who is the Chief of the Logistic Sector, for his contribution in providing necessary information which was critical to this article.

We would also like to thank the following: Roger Hopkinson (UK) for his assistance checking grammar; Dr.Gregory Cowan RIBA, for his assistance in proofreading, scientific logic and referencing; although the authors remain responsible for any errors which remain; Professor Kun Song, for his valuable suggestions during the writing process, and finally, the authors would like to express special thanks to the National Natural Science Foundation of China for covering all expenses.

\section{Author information}

Abduxukur Zayit (阿不都西库尔. 扎依提), Ph.D. Candidate at School of Architecture, Tianjin University, Tianjin 300072, China; Lecturer at College of Hydraulic and Civil Engineering, Xinjiang Agricultural University, Ürümchi, Xinjiang Uyghur Autonomous Region,830052, China; Dedicated to green building, sustainable campus, and research of Uyghur Architecture (Xinjiang Uyghur Autonomous Region).

Phone: +08617710149540; E-mail: abdushukur.zayit@aliyun.com 


\begin{tabular}{|c|c|c|c|}
\hline Destination & $\begin{array}{l}\text { From the } \\
\text { west gate } \\
\text { in }(\mathbf{k m})\end{array}$ & $\begin{array}{c}\text { From the east } \\
\text { gate in }(\mathbf{k m})\end{array}$ & $\begin{array}{c}\text { From the east } \\
\text { gate in }(\mathbf{k m})\end{array}$ \\
\hline 1 & 2.440 & 2.000 & 0.360 \\
\hline 2 & 1.860 & 2.020 & 0.600 \\
\hline 3 & 2.500 & 1.582 & 0.440 \\
\hline 4 & 2.000 & 1.560 & 1.600 \\
\hline 5 & 2.000 & 1.560 & 1.600 \\
\hline 6 & 1.720 & 1.280 & 1.320 \\
\hline 7 & 1.200 & 0.820 & 1.360 \\
\hline 8 & 1.080 & 1.080 & 1.400 \\
\hline 9 & 1.560 & 0.980 & 0.960 \\
\hline 10 & 1.340 & 1.320 & 1.220 \\
\hline 11 & 0.980 & 1.840 & 1.500 \\
\hline 12 & 0.800 & 2.000 & 1.740 \\
\hline 13 & 0.820 & 2.400 & 1.680 \\
\hline 14 & 0.720 & 2.400 & 1.840 \\
\hline 15 & 0.700 & 1.440 & 1.760 \\
\hline 16 & 0.460 & 1.700 & 2.200 \\
\hline 17 & 0.160 & 2.080 & 2.660 \\
\hline 18 & 0.600 & 1.460 & 2.200 \\
\hline 19 & 1.160 & 0.940 & 1.700 \\
\hline 20 & 1.360 & 0.760 & 1.520 \\
\hline 21 & 1.480 & 0.560 & 1.560 \\
\hline Average & 1.282 & 1.513 & 1.486 \\
\hline \multicolumn{3}{|c|}{ Average } & 1.427 \\
\hline \multicolumn{2}{|c|}{$\begin{array}{l}\text { East Gate to West Gate } \\
\text { (Return) }\end{array}$} & \multicolumn{2}{|c|}{1.940} \\
\hline \multicolumn{2}{|c|}{$\begin{array}{l}\text { North Gate to West Gate } \\
\text { (Return) }\end{array}$} & \multicolumn{2}{|c|}{2.500} \\
\hline \multicolumn{2}{|c|}{$\begin{array}{l}\text { North Gate to East Gate } \\
\text { (Return) }\end{array}$} & \multicolumn{2}{|c|}{1.940} \\
\hline \multicolumn{2}{|c|}{$\begin{array}{l}\text { North Gate to South Gate } \\
\text { (Return) }\end{array}$} & \multicolumn{2}{|c|}{1.746} \\
\hline \multicolumn{2}{|c|}{$\begin{array}{l}\text { East Gate to South Gate } \\
\text { (Return) }\end{array}$} & \multicolumn{2}{|c|}{0.940} \\
\hline \multicolumn{2}{|c|}{$\begin{array}{l}\text { West Gate to South Gate } \\
\text { (Return) }\end{array}$} & \multicolumn{2}{|c|}{1.500} \\
\hline \multicolumn{2}{|c|}{ Average } & \multicolumn{2}{|c|}{$1.761 \mathrm{~km}$} \\
\hline \multicolumn{2}{|c|}{$\begin{array}{c}\text { Overall average distance } \\
\text { travelled inside the } \\
\text { campus }\end{array}$} & \multicolumn{2}{|c|}{$1.594 \mathrm{~km}$} \\
\hline
\end{tabular}


Appendix B: Average distance travelled inside Peiyangyuan Campus

\begin{tabular}{|c|c|c|c|c|c|}
\hline Destination & $\begin{array}{c}\text { From the } \\
\text { north } \\
\text { gate in }(\mathbf{k m})\end{array}$ & $\begin{array}{c}\text { From the } \\
\text { northeast } \\
\text { Gate in }(\mathbf{k m}) \\
\end{array}$ & $\begin{array}{c}\text { From the } \\
\text { east gate in } \\
(\mathrm{km})\end{array}$ & $\begin{array}{c}\text { From the } \\
\text { southeast gate }(\mathbf{k m})\end{array}$ & $\begin{array}{l}\text { From the } \\
\text { south } \\
\text { gate }(\mathrm{km})\end{array}$ \\
\hline 1 & 4.08 & 3.36 & 2.02 & 0.20 & 2.20 \\
\hline 2 & 3.8 & 3.56 & 2.26 & 1.00 & 1.64 \\
\hline 3 & 3.8 & 3.16 & 1.80 & 0.40 & 2.00 \\
\hline 4 & 1.4 & 3.48 & 2.12 & 1.40 & 0.4 \\
\hline 5 & 2.3 & 4.18 & 2.74 & 2.06 & 0.2 \\
\hline 6 & 3.68 & 3.36 & 0.96 & 1.26 & 2.04 \\
\hline 7 & 3.6 & 2.86 & 1.40 & 0.82 & 1.60 \\
\hline 8 & 3.36 & 2.6 & 1.24 & 1.32 & 2.06 \\
\hline 9 & 3.24 & 2.6 & 0.60 & 3.00 & 3.96 \\
\hline 10 & 2.8 & 2.12 & 1.04 & 2.40 & 3.34 \\
\hline 11 & 2.32 & 1.58 & 1.48 & 2.26 & 2.92 \\
\hline 12 & 1.98 & 1.26 & 1.86 & 2.62 & 3.38 \\
\hline 13 & 1.66 & 1.30 & 2.24 & 2.72 & 3.42 \\
\hline 14 & 2.00 & 0.84 & 2.40 & 2.86 & 3.52 \\
\hline 15 & 1.68 & 0.96 & 3.00 & 3.00 & 3.24 \\
\hline 16 & 2.76 & 0.20 & 3.00 & 3.40 & 3.80 \\
\hline 17 & 2.4 & 0.64 & 2.66 & 3.10 & 3.60 \\
\hline 18 & 1.2 & 1.54 & 3.40 & 4.00 & 2.60 \\
\hline 19 & 1.2 & 1.98 & 3.00 & 4.20 & 2.24 \\
\hline 20 & 1.36 & 3.12 & 3.40 & 3.16 & 1.44 \\
\hline 21 & 1.9 & 3.66 & 3.36 & 2.60 & 1.00 \\
\hline Average & 2.50 & 2.30 & 2.19 & 2.28 & 2.40 \\
\hline \multicolumn{3}{|c|}{ Average } & $2.33 \mathrm{~km}$ & & \\
\hline \multicolumn{2}{|c|}{$\begin{array}{l}\text { North Gate to Northeast Gate } \\
\text { (Return) }\end{array}$} & \multicolumn{2}{|c|}{2.8} & & \\
\hline \multicolumn{2}{|c|}{$\begin{array}{l}\text { North Gate to East Gate } \\
\text { (Return) }\end{array}$} & \multicolumn{2}{|c|}{3.8} & & \\
\hline \multicolumn{2}{|c|}{$\begin{array}{l}\text { North Gate to Southeast Gate } \\
\text { (Return) }\end{array}$} & \multicolumn{2}{|c|}{4.2} & & \\
\hline \multicolumn{2}{|c|}{$\begin{array}{l}\text { North Gate to South Gate } \\
\text { (Return) }\end{array}$} & \multicolumn{2}{|c|}{2.4} & & \\
\hline \multicolumn{2}{|c|}{$\begin{array}{l}\text { Northeast Gate to East Gate } \\
\text { (Return) }\end{array}$} & \multicolumn{2}{|c|}{3} & & \\
\hline \multicolumn{2}{|c|}{$\begin{array}{l}\text { Northeast Gate to Southeast } \\
\text { gate (Return) }\end{array}$} & \multicolumn{2}{|c|}{3.6} & & \\
\hline \multicolumn{2}{|c|}{$\begin{array}{l}\text { Northeast Gate to South Gate } \\
\text { (Return) }\end{array}$} & \multicolumn{2}{|c|}{4.2} & & \\
\hline \multicolumn{2}{|c|}{$\begin{array}{l}\text { East Gate to Southeast Gate } \\
\text { (Return) }\end{array}$} & \multicolumn{2}{|c|}{2.06} & & \\
\hline \multicolumn{2}{|c|}{$\begin{array}{l}\text { East Gate to South Gate } \\
\text { (Return) }\end{array}$} & \multicolumn{2}{|c|}{2.86} & & \\
\hline \multicolumn{2}{|c|}{$\begin{array}{c}\text { Southeast Gate to South } \\
\text { Gate(Return) }\end{array}$} & \multicolumn{2}{|c|}{2.2} & & \\
\hline \multicolumn{2}{|c|}{ Average } & \multicolumn{2}{|c|}{$3.11 \mathrm{~km}$} & & \\
\hline \multicolumn{2}{|c|}{$\begin{array}{l}\text { Overall average distance } \\
\text { travelled inside the campus }\end{array}$} & \multicolumn{2}{|c|}{$2.72 \mathrm{~km}$} & & \\
\hline
\end{tabular}




\section{References:}

(2021), "Calculation of Carbon Emission During Expressway Operation Period Based on Energy Consumption Analysis", IOP Conference Series: Earth and Environmental Science, Vol. 647 No. 1, pp. 012190 (6pp).

ABDELALIM, A., O BRIEN, W. \& SHI, Z. (2015), "Visualization of energy and water consumption and GHG emissions: A case study of a Canadian University Campus", Energy and Buildings, Vol. 109334-352.

ADEYEMI, A. (2018), "Development of Carbon Dioxide Emission Assessment Tool towards Promoting Sustainability in UTM Malaysia", Open Journal of Energy Efficiency, Vol. 7 No. 2, pp.

ARNDT, C., MISSELBROOK, T. H., VEGA, A., GONZALEZ-QUINTERO, R., CHAVARRO-LOBO, J. A., MAZZETTO, A. M. \& CHADWICK, D. R. (2020), "Measured ammonia emissions from tropical and subtropical pastures: A comparison with 2006 IPCC, 2019 Refinement to the 2006 IPCC, and EMEP/EEA (European Monitoring and Evaluation Programme and European Environmental Agency) inventory estimates", Journal of Dairy Science, Vol. 103 No. 7, pp. 6706-6715.

BOUSCAYROL, A., CASTEX, E., DELARUE, P., DESREVEAUX, A., FERLA, O., FROTEY, J., GERMAN, R., KLEIN, J., LHOMME, W. \& SERGENT, J. F. (2017), "Campus of University with Mobility based on Innovation and carbon Neutral", in 2017 IEEE Vehicle Power and Propulsion Conference (VPPC), IEEE, pp. 15 .

BROWN, D. (2021) Why China's climate policy matters to us all..

BUTT, L., MORE, E. \& AVERY, G. (2009), "Sustainability education and professional development programs for managers in Australian universities", in Proceedings of the 23rd Australia New Zealand Academy of Management Conference, pp.

CHANG, C. C., SHI, W., MEHTA, P. \& DAUWELS, J. (2019), "Life cycle energy assessment of university buildings in tropical climate", Journal of Cleaner Production, Vol. 239117930.

CHEN YUE, Z. (2016) Carbon emissions calculation of Shandong Jianzhu University., Shandong Jianzhu University.

CHINA PLUS, C. (2020) Xi: China aims to achieve carbon neutrality by 2060.

CHINA, M. O. E. A. (1996) National Action Plan for Environmental Publicity and Education..

CHINA, M. O. E. A. (2001) National Environmental Education and Promotion plan of 2001-2005..

CHINA, M. O. H. A. (2009) Technical guide for Colleges and Universities building energy efficiency supervision system..

CHINA, M. O. H. A. (2021) General standard for building energy conservation and renewable energy utilization.. CHINA, N. D. A. R. (2014) China's Regional state grid average carbon dioxide emission factor for 2011-2012..

CHINA, T. M. O. I. (2020) 2019 Chinese automobile enterprises Corporate Average Fuel Consumption..

COM, T. (2015) how much carbon emission for 1 tonne tab water..

COMMISSION, T. D. A. R. (2013) Guide for Carbon Emission accounting of Electronic Power Industry for Tianjin..

DENISON (2010) Presidents' Climate Commitment..

DEVELOPMENT, C. B. C. F. (2011) Provincial Guidelines for Greenhouse Gas Inventories(PGGGI).

DEVELOPMENT, U. I. O. E. (2021) Campus Carbon Neutrality by 2050: China Green University Network Releases Joint Declaration

EDENHOFER, O. (2015), Climate change 2014: mitigation of climate change, Cambridge University Press.

EVANGELINOS, K. I., JONES, N. \& PANORIOU, E. M. (2009), "Challenges and opportunities for sustainability in regional universities: a case study in Mytilene, Greece", Journal of Cleaner Production, Vol. 17 No. 12, pp. 1154-1161.

FUTURE, T. A. O. U. (2021) Talloires Declaration Signatories List

GARCÍA, R. \& FREIRE, F. (2014), "Carbon footprint of particleboard: a comparison between ISO/TS 14067, GHG Protocol, PAS 2050 and Climate Declaration", Journal of cleaner production, Vol. 66199-209.

GARDEN, L. V. B. (2021) The calculation of the landscape carbon budget of campus green space-—Taking Beiyang Plaza of Tianjin University as a case.

GUO XINXIANG, W. H. H. (2010), "The research on CO2-fixing of green plants ways in residential quarters", in Paper Collection for the Sixth International Conference on Green and Energy-Efficient Building, Beijing, pp. 150- 154.

HELMERS, E., CHANG, C. C. \& DAUWELS, J. (2021), "Carbon footprinting of universities worldwide: Part I-objective comparison by standardized metrics", Environmental Sciences Europe, Vol. 33 No. 1, pp. 30.

HUANG BOWEI, L. B. (2016), "Performance of Low Carbon for Campus Canteen:

A Case Study in the Campus Cafeteria in Peking University", Acta Scientiarum Naturalium Universitatis 
Pekinensis, Vol. 2 No. 52, pp. 320-326.

IEA (2021) CO2 emissions from fuel combustion in selected economies, 2000-2019..

INFORMATION, N. P. S. P. (2020) General rules for calculation of the comprehensive energy consumption

IPCC (1990) Introduction of IPCC first report.

IPCC (2016) United Nations Framework Convention on Climate Change..

JUNG, J., HA, G. \& BAE, K. (2016), "Analysis of the factors affecting carbon emissions and absorption on a university campus - focusing on Pusan National University in Korea", Carbon Management, Vol. 7 No. 1-2, pp. $55-65$.

LÉLÉ, S. M. (1991), "Sustainable development: a critical review", World development, Vol. 19 No. 6, pp. 607621.

LI, X., TAN, H. \& RACKES, A. (2015), "Carbon footprint analysis of student behavior for a sustainable university campus in China", Journal of Cleaner Production, Vol. 10697-108.

LONDON, K. C. (2020) ENVIRONMENTAL SUSTAINABILITY Report 2018-2019..

LÜNEBURG, L. U. (2015) Jahresabschluss und Lagebericht für das Geschäftsjahr 2015.

MCGRATH, M. (2021) Climate change: IPCC report is 'code red for humanity'..

MINISTRY OF HOUSING AND URBAN-RURAL DEVELOPMENT, P. M. C. (2019) (2019).

Assessment standard for green campus(GB/T 51356-2019)..

NADERIPOUR, A., ABDUL-MALEK, Z., ARSHAD, R. N., KAMYAB, H., CHELLIAPAN, S., ASHOKKUMAR, V. \& TAVALAEI, J. (2021), "Assessment of carbon footprint from transportation, electricity, water, and waste generation: towards utilisation of renewable energy sources", Clean Technologies and Environmental Policy, Vol. 23 No. 1, pp. 183-201.

NATIONS, U. (1972) Report on the United Nations Conference on the Human enviroment..

NTU (2017) NTU annual report 2017..

NUNES, L. M., CATARINO, A., TEIXEIRA, M. R. \& CUESTA, E. M. (2013), "Framework for the intercomparison of ecological footprint of universities", Ecological indicators, Vol. 32276-284.

OPEL, O., STRODEL, N., WERNER, K. F., GEFFKEN, J., TRIBEL, A. \& RUCK, W. K. L. (2017), "Climateneutral and sustainable campus Leuphana University of Lueneburg", Energy, Vol. 1412628-2639.

PLC, B. (2021) Statistical Review of World Energy $2021 .$.

QUEENSLAND, T. U. O. (2015) Annual Report 2015..

RIDHOSARI, B. \& RAHMAN, A. (2020), "Carbon footprint assessment at Universitas Pertamina from the scope of electricity, transportation, and waste generation: Toward a green campus and promotion of environmental sustainability", Journal of Cleaner Production, Vol. 246119172.

RIPPON, S. \& DESIGN, B. (2014), "University of Cape Town Carbon Footprint Report 2013", Cape Town: University of Cape Town,

ROCHE, M. Y., LECHTENBOEHMER, S., FISCHEDICK, M., GROENE, M. C., XIA, C. \& DIENST, C. (2014), "Concepts and Methodologies for Measuring the Sustainability of Cities", Annual Review of Energy and the Environment, Vol. 39519-547.

ROSEN, A. M. (2015), "The wrong solution at the right time: The failure of the Kyoto protocol on climate change", Politics \& Policy, Vol. 43 No. 1, pp. 30-58.

SANGWAN, K. S., BHAKAR, V., ARORA, V. \& SOLANKI, P. (2018), "Measuring Carbon Footprint of an Indian University Using Life Cycle Assessment", Procedia CIRP, Vol. 69475-480.

SURESH, B. K., MOONDRA, N. \& TANDEL, B. N. (2021), "Assessment of Carbon Foot Print: A Case Study of SVNIT Campus", Recent Trends in Civil Engineering. Springer, pp. 1029-1039.

TOWN, U. O. C. (2013) Annual financial statements..

UNECE (2005) COPERNICUS-Guidelines for Sustainable Development in the European Higher Education Area

, How to incorporate the principles of sustainable development into the Bologna Process..

UNESCO (2022) Education for sustainable development..

UNIVERSITY, M. S. (2019) MINNESOTA STATE UNIVERSITY-MANKATO.

UNIVERSITY, M. (1990) TALLOIRES DECLARATION.

UNIVERSITY, M. (2016) annual report 2016.

UNIVERSITY, T. (2019) Tianjin University 2018 - 2019 First/Second Semester Academic Calendar..

UNIVERSITY, T. (2020a) TJU Facts.

UNIVERSITY, T. (2020b) TJU Facts.

UNIVERSITY, T. (2020c) Tianjin University financial report $2019 .$.

UNIVERSITY, Y. (2016) Yale financial report 2015 - 2016.

WACKERNAGEL, M. \& REES, W. (1998), Our ecological footprint: reducing human impact on the earth, New society publishers.

WBCSD, W. (2004), "The greenhouse gas protocol", A corporate accounting and reporting standard, Rev. ed. 
Washington, DC, Conches-Geneva,.

WIEDMANN, T. \& MINX, J. (2008), "A definition of 'carbon footprint' ", Ecological economics research trends, Vol. 11-11.

WINTERGREEN, J. \& DELANEY, T. (2007), "ISO 14064, international standard for GHG emissions inventories and verification", in 16th Annual International Emissions Inventory Conference, Raleigh, NC, pp.

WRI, W. (2004), "The greenhouse gas protocol: A corporate accounting and reporting standard", World Resources Institute (WRI) and World Business Council for Sustainable Development (WBCSD), Washington, DC and Geneva,.

Y ZHENG, C. F. J. K. (2011), "A Study of Sustainable Campuses Based on the Ecological Footprint Model: A Case Study of Peking University", Resources Science, Vol. 33 No. 06, pp. 1163-1170.

YAÑEZ, P., SINHA, A. \& VÁSQUEZ, M. (2020a), "Carbon Footprint Estimation in a University Campus: Evaluation and Insights", Sustainability

, Vol. 12 No. 1, pp. 181

YAÑEZ, P., SINHA, A. \& VÁSQUEZ, M. (2020b), "Carbon footprint estimation in a university campus: evaluation and insights", Sustainability, Vol. 12 No. 1, pp. 181.

YAZDANI, Z., TALKHESTAN, G. A. \& KAMSAH, M. (2013), "Assessment of carbon footprint at university technology Malaysia (UTM)", in Applied Mechanics and Materials, Trans Tech Publ, pp. 872-875.

YI, J. \& SHAN, H. (2021), "Paths to carbon neutrality in China's building sector", Heating Ventilating \& Air Conditioning, Vol. 51 No. 05, pp. 1-13.

ZHAO, R. Q., HUANG, X. J., GAO, S., ZHAO, Z. \& TAN, D. (1762), "Research on estimation and reduction potential of carbon emission in Jiangsu Province, China", in The Second Energy Scientist Forum, pp.

ZHU, B. \& DEWANCKER, B. (2021), "A case study on the suitability of STARS for green campus in China", Evaluation and Program Planning, Vol. 84101893.

ZHU, B. \& DEWANCKER, B. (2021), "A case study on the suitability of STARS for green campus in China", Evaluation and Program Planning, Vol. 84101893.

ZHU, B., WANG, Z., SUN, C. \& DEWANCKER, B. (2021), "The motivation and development impact of energy saving to sustainability in the construction of green campus: a case study of the Zhejiang University, China", Environment, Development and Sustainability, Vol. 23 No. 9, pp. 14068-14089.

ZHU, B., WANG, Z., SUN, C. \& DEWANCKER, B. (2021), "The motivation and development impact of energy saving to sustainability in the construction of green campus: a case study of the Zhejiang University, China", Environment, Development and Sustainability, 1-22.

ZOURAN, Z. C. F. T. (2017), "Research on low-carbon construction strategy of campus in cold area based on carbon balance accounting", resources and environment, No. 4, pp. 144-150. 